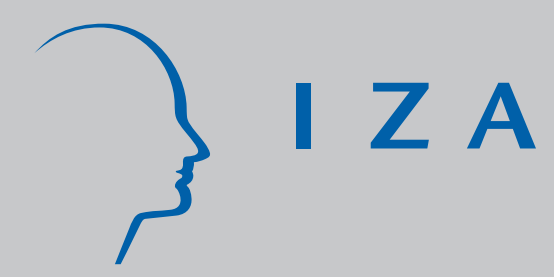

IZA DP No. 184

Intergenerational Influences on the Receipt of Unemployment Insurance in Canada and Sweden

Miles Corak

Björn Gustafsson

Torun Österberg

August 2000 


\title{
Intergenerational Influences on the Receipt of Unemployment Insurance in Canada and Sweden
}

\author{
Miles Corak \\ Statistics Canada and Carleton University \\ Björn Gustafsson \\ University of Göteborg and IZA, Bonn \\ Torun Österberg \\ University of Göteborg \\ Discussion Paper No. 184 \\ August 2000 \\ IZA \\ P.O. Box 7240 \\ D-53072 Bonn \\ Germany \\ Tel.: +49-228-3894-0 \\ Fax: +49-228-3894-210 \\ Email: iza@iza.org
}

This Discussion Paper is issued within the framework of IZA's research area The Welfare State and Labor Markets. Any opinions expressed here are those of the author(s) and not those of the institute. Research disseminated by IZA may include views on policy, but the institute itself takes no institutional policy positions.

The Institute for the Study of Labor (IZA) in Bonn is a local and virtual international research center and a place of communication between science, politics and business. IZA is an independent, nonprofit limited liability company (Gesellschaft mit beschränkter Haftung) supported by the Deutsche Post AG. The center is associated with the University of Bonn and offers a stimulating research environment through its research networks, research support, and visitors and doctoral programs. IZA engages in (i) original and internationally competitive research in all fields of labor economics, (ii) development of policy concepts, and (iii) dissemination of research results and concepts to the interested public. The current research program deals with (1) mobility and flexibility of labor markets, (2) internationalization of labor markets and European integration, (3) the welfare state and labor markets, (4) labor markets in transition, (5) the future of work, (6) project evaluation and (7) general labor economics.

IZA Discussion Papers often represent preliminary work and are circulated to encourage discussion. Citation of such a paper should account for its provisional character. 
IZA Discussion Paper No. 184

August 2000

\section{ABSTRACT \\ Intergenerational Influences on the Receipt of Unemployment Insurance in Canada and Sweden*}

The objective of this paper is to examine the extent to which an individual's use of unemployment insurance (UI) as a young adult is influenced by past experience with the program, and by having had a parent who also collected UI. A major methodological challenge is to determine the extent to which the intergenerational correlation of UI status is "spurious" or causal. Both the time to a first UI claim and the entire sequence of claims over an extended period are examined using two alternative ways of controlling for unobserved heterogeneity. The analysis is based upon longitudinal data on a cohort of young Canadian and Swedish men. It is found that parental use of UI shortens the time to a first UI claim in Canada, but not in Sweden. Subsequent participation in the Canadian program is influenced by parental UI history. In Sweden individual learning through past participation in UI-not family background-is the dominant avenue determining repeated participation.

JEL Classification I38, J62, J65

Keywords: Unemployment insurance, intergenerational mobility, unemployment

Miles Corak

Family and Labour Studies

Statistics Canada

Ottawa, Canada K1A 0T6

Tel.: 1613 951-9047

Fax: $1613951-5403$

Email: miles.corak@statcan.ca

\footnotetext{
* An earlier version of this paper was presented to seminars at Statistics Canada, Department of Finance Canada, University of Manitoba, University of Ottawa, Dalhousie Univeristy, Carleton University as well as to the meetings of the European Society for Population Economics, the Canadian Economics Association, and the Centre for the Study of Living Standards conference on Structural Unemployment. Comments from Laura Brown, Seamus Hogan, Stephen Jones, Ted MacDonald, Alice Nakamura, Bill Robson, and Christopher Worswick are gratefully acknowledged, as is the help of Sophie Lefebvre in constructing the data. We also thank Timothy Sargent for providing an index of Canadian UI program parameters. The responsibility for the content of this paper rests entirely with the authors, and in particular should not be attributed to Statistics Canada.
} 


\section{INTERGENERATIONAL INFLUENCES ON THE RECEIPT OF UNEMPLOYMENT INSURANCE IN CANADA AND SWEDEN}

In the often cited Jobs Study the OECD asserts that the labour supply disincentives associated with a more generous unemployment insurance program can be very long and that this represents the basis for persistently high unemployment rates in some industrialized countries. For example, it is suggested that the lags in the impact of UI benefit liberalization in Canada may be in the order of 5 to 10 years, and as long as 10 to 20 years in some Scandinavian countries, notably Sweden and Norway (OECD 1994, p.178). The Jobs Study, however, did not make clear the underlying mechanisms contributing to these long lags. In fact, Ljungqvist and Sargent (1998) argue that they are purely coincidental and that the reason for persistently high unemployment in the European countries has to do with a changed economic climate. In their view, higher unemployment rates are the result of more turbulent labour markets—particularly labour markets characterized by state dependence in the duration of unemployment spellsinteracting with a welfare state originally designed during more tranquil times. Without denying the relevance of this hypothesis, our objective in this paper is to explore possible direct explanations for lags in UI disincentives that could conceivably be measured in decades. Lindbeck (1995), for example, places an important emphasis on the longer run disincentives of social insurance programs associated with changes in habits and social norms. He suggests that it may take considerable time before the complete labour market consequences of a change in program rules becomes apparent because individuals feel constrained by prevailing norms of behaviour and are reluctant to take-up benefits to 
which they are entitled. He offers a number of explanations of how standards of behaviour may change, and explicitly suggests that "changes in habits, norms, attitudes, and ethics are particularly likely to occur when a new generation enters working life and forms its values on the basis of a new incentive structure" $(1995, \mathrm{p} .11)$. This is the theme explored in our research.

However, in doing so we also examine the extent to which an individual's participation in UI is influenced by having had parents who collected UI in the past. There are a number of competing (but not mutually exclusive) explanations for an intergenerational correlation in the receipt of UI. These include the intergenerational transmission of information about how the UI program works, or more generally learning and the formation of habits. If these causal pathways exist between parents and children then it may be reasonable to suggest that events raising unemployment rates and UI participation at a point in time may echo into the next decade or two as the following generation becomes active in the labour market. However, a major methodological challenge in documenting a causal intergenerational link involves determining the extent to which any correlation is due to intergenerational correlation of incomes, occupations, or other potentially unobservable factors common to parents and children that influence the chances of becoming unemployed. If these factors cannot be controlled for there is a risk of overstating the causal impact of parental activities on the longer-term outcomes of their children.

The research summarized in this paper actually fits into a number of related literatures dealing with intergenerational dynamics. These are discussed in more detail in the next section in the context of a schematic overview of the analysis. The empirical 
work is based upon longitudinal administrative data associated with the Canadian and Swedish income tax systems that have been linked intergenerationally, and focuses on the pattern of UI use by a cohort of young men and how it relates to the UI use of their fathers. These two countries offer a valuable basis for comparative work because their economies display many structural similarities. They have also both directed significant resources toward labour market policy. However, the mix between active and passive labour market measures is rather different. In Canada the emphasis is almost exclusively on "passive" income support, while in Sweden significant expenditures are made on "active" measures designed to promote labour market flexibility. Also the eligibility rules school leavers must meet to qualify in order to claim benefits differs between the countries: the Canadian program requiring a work requirement to be satisfied; the Swedish program requiring only a period of joblessness. Attitudes to UI and the consequences for intergenerational transmission may be very different between these two regimes.

The nature of the data is discussed in section 2. An outline of the estimation strategies is also offered in this section. Two alternative approaches are employed. First, event history methods are used to model how long it takes before an individual claims UI for the first time. The methodology proposed by Gottschalk (1996) is employed to estimate the degree to which a parent's reliance on UI causes children to use UI as young adults. This involves using a parent's future UI participation as a control for unobserved heterogeneity. Second, a random effects probit model is used to model the entire history of UI benefit receipt on an annual basis for a 12 to 15 year period beginning at age 16 . In this latter model a distinction is made between "individual" learning and "social capital" 
in the sense that these terms are used respectively by Lemieux and MacLeod (1998) and Becker (1996). In this way we also examine the relative importance of individual learning and family background in determining program use.

The results are offered in section 3. We find that parental use of UI plays a role in shortening the time to the first use of this program by the sample of men under study, but only in Canada. The conditional probability of using UI at any age between 16 and 30 is higher among those whose parents used UI in the past with the result that only about $24 \%$ reach the age of 30 without having collected benefits versus about $32 \%$ of their counterparts whose parents did not collect. This difference is due in about equal proportions to the role of unobservables and to the causal impact of parental UI use. Furthermore, subsequent individual UI use is governed to a greater degree by parental UI history than by individual learning about the program. In contrast, the intergenerational correlation of first use of UI in Sweden can be entirely accounted for by unobservables. Subsequent participation in UI is substantially higher as a result of individual learning about the program. We suggest that these results call for a closer analysis of the significance of an active program design, as well as the eligibility rules facing new labour market entrants, for the intergenerational transmission of labour market disincentives.

\section{AN OVERVIEW}

A comparative analysis of the Canadian and Swedish labour markets is offered in van den Berg, Furåker, Johansson (1997, chapter 3) who note that, except for possible differences in the relative size of the public and the service sectors, the two economies are remarkedly similar. Further, both countries also have had about the same level of 
expenditures on labour market policies. Throughout the 1970s and early 1980s, the most significnat years for our analysis, this amounted to between 2 and 3 percent of GDP, with Sweden generally spending a bit more in most years than Canada. However, the pattern of expenditure has been very different. In Canada, passive income support through UI accounted for almost 2 percent of GDP, but generally only between 0.5 and 0.75 percent in Sweden. In fact, income support through UI accounted for only about 10 to 15 percent of total Swedish expenditure on labour market policy in the 1970s and about 25 percent during the 1980s. In Canada, on the other hand, this was in the neighbourhood of 70 to 80 percent (van den Berg, Furåker, Johansson 1997, p.46; Gustafsson and Klevmarken 1993, p.119; OECD 1992, pp. 93, 101).

The Canadian UI program is administered by the federal government, which holds the responsibility for both collecting contributions and distributing benefits. The benefit structure has its roots in a major reform in 1971. Most paid workers, with the exception of the self-employed, are covered by the program, and are eligible to receive benefits upon becoming unemployed if they had worked a sufficient number of weeks during the qualifying period (generally the previous year). Throughout the 1970s and 1980s this eligibility rule varied from about 10 to 14 weeks of insured employment depending upon the state of the regional labour market. However, new entrants to the labour market, including school leavers, had a longer work requirement: generally 20 weeks. Benefits could be collected for up to 50 weeks (again depending upon the regional unemployment rate) at a rate of 60 to 67 percent of insured earnings. A two week waiting period was 
also required before benefits could be collected. Generally, up to the 1990 s about 70 to $80 \%$ of the unemployed received benefits. ${ }^{1}$

A reform in the early 1970 s also expanded the scope of the Swedish program. UI benefits were not that generous before 1974, covering only those who were members of union based insurance funds. This amounted to about $60 \%$ of the employed. In 1974 a reform increased the generosity of benefits for these individuals, but also made the benefits taxable. A second tier of benefits was also introduced and financed by the government - the KAS - for those who were not members of an insurance fund. ${ }^{2}$ Thus, to qualify for benefits individuals had, on the one hand, to have been a member of an insurance fund for at least 12 months in the period before the claim, and to have fulfilled a work requirement of at least 75 days. (There are also a host of other requirements.) If they were not members of a fund they could qualify for the KAS after meeting the same work requirement. However, in sharp contrast to the Canadian program, school leavers could qualify for benefits after a waiting period of three months, without regard to their actual work experience. Generally, benefits for members of insurance funds lasted about 300 days, and about half of that in the case of KAS. Benefit rates increased during the 1970s and 1980s for those fulfilling the membership requirements—from about $70 \%$ of average earnings to about $90 \%$ for those with earnings below a certain ceiling-but were generally much lower for the KAS. Further, coverage increased throughout this period so that the majority of the unemployed were by the mid to late 1980 s members of an

\footnotetext{
${ }^{1}$ There have been major reforms to the Canadian program during the 1990s, and in fact it is now referred to as "Employment Insurance." These reforms had the effect of reducing the scope of the program to levels before the 1971 reforms. See Sargent (1995) and Canada (1995) for a description of these changes and their impact. Since 1990 the fraction of unemployed receiving benefits has fallen, reaching about $40 \%$ in 1998 .

${ }^{2}$ While the insurance funds are formally union based, the government determines the most important parameters, including the benefit rate and the eligibility requirements.
} 
insurance fund. In 1988, for example, 69\% of the unemployed received insurance benefits, a further 7\% KAS, and the remaining $25 \%$ received no benefits at all. In 1993, the replacement rate was reduced to $80 \%$.

The labour market consequences of UI have been the subject of numerous studies. Atkinson and Micklewright (1991) offer a helpful reivew. But the surveys by Gustafsson and Klevmarken (1993) and Bjorklund (1991) of the Swedish literature, and by Corak (1994) of the Canadian, are important for present purposes. The general message from these sources is that while the impact of changes in UI generosity on the aggregate unemployment rate remains unclear, there is nonetheless a good deal of evidence suggesting that the behaviour of both firms and individuals is influenced. In particular, an increasingly larger and larger fraction of Canadian UI claims are accounted for by individuals who have repeatedly initiated UI claims since the notable liberalization of the program in 1972 (Corak 1992, Lemieux and MacLeod 1995). The OECD (1994, p.198) suggests that a similar pattern has developed in Sweden, and Ackum Agell, Björklund and Harkman (1995) offer some evidence suggesting that repeated spells are in fact common.

A schematic overview of the determinants of the incidence of an insured spell of unemployment is offered in Figure 1 as a means of organizing the existing literature on this topic, and of offering a framework for a study of the intergenerational influences. A major concern in this literature is the degree to which past use of UI causes future use. This is a form of state dependence that Heckman and Borjas (1980) have termed "occurrence dependence," and is indicated in Figure 1 by the solid horizontal arrow connecting the very first spell of UI an individual experiences to subsequent spells. The 
challenge in this literature is to control for other factors that may also determine the onset of an insured unemployment spell. These influences may work directly on the probability of receiving a spell, or just as importantly through the onset of earlier spells. Past spells will appear to cause future spells, when in fact they really are a signal of other underlying influences. Region of residence is highlighted in Figure 1 as one group of potentially important influences on the incidence of UI, and encompasses factors associated with industrial structure, particularly the seasonality of employment, aggregate labour market conditions, and (since the parameters of the unemployment insurance system vary according to the regional unemployment rate) the generosity of the UI program. Corak (1993a), for example, points out that there is a very important regional divide in Canada in the incidence of repeat UI use with individuals living in provinces east of the Ottawa River experiencing a higher claim rate than those to the west. Other possible influences include the occupation, industry and even firm of employment. Corak and Pyper (1995) document the fact that in Canada a minority of firms within any particular industry, are responsible for the majority of UI claims initiated by the workers of that industry. This raises the possibility that the employment strategies of specific firms may play a role in determining the incidence of repeat UI use. Many of these influences will be observable, but some, like the specific employer, will inevitably be unobservable to the analyst. Meyer and Rosenbaum (1996) and Anderson and Meyer (1993) offer similar U.S. evidence on the nature of repeat UI use and importance of individual firms in the process.

There seems to be some evidence to suggest that the onset of a UI claim is caused by the presence of past claims. Corak (1993b) and Lemieux and MacLeod (1998) explicitly address the possibility of occurrence dependence, controlling for a host of 
observable individual characteristics, and employing econometric methods to control for unobservables. In particular, Corak (1993b) uses the fixed-effects framework put forward by Heckman and Borjas (1980) to document the fact that each subsequent UI claim for an individual is longer than the previous, suggesting that the underlying process determining the length of spells is changing with past use. Lemieux and MacLeod (1998) model the entire sequence of spells experienced over a 20 year period using random-effects probit models and find, in general, that the probability of starting a new UI claim is higher if the individual had a claim in the past. How this pattern of behaviour is to be explained remains an issue. Corak (1993b) does not attempt to impose an interpretation suggesting only that the results are consistent with models in which tastes, habits, or information change as a result of participating in the program. This would also be consistent with the erosion of a stigma to the receipt of government transfers of the kind discussed for example in Moffit (1983), or possibly with models of rational addiction in the spirit of Becker and Murphy (1988). Lemieux and MacLeod are more explicit and view their findings as supporting the idea that individuals learn about the program. They focus on "individual" learning, but note that by implication some of their results also lend support for "social" learning. While their analysis does not directly address the possibility of social learning, they do find that the influence of an individual's past UI use on the probability of future use is lower in regions of the country with a high reliance on UI, namely the Atlantic. The suggestion being that information about the UI program is widespread, and picked up by an individual from family and friends without the need to have actually made a claim. ${ }^{3}$

\footnotetext{
${ }^{3}$ The anomalous finding in their paper, however, is that the individual learning effects are strongest for the older cohorts they examine. For the younger groups the individual learning effect is often statistically
} 
This is the theme that we build upon by focusing on the role of family background in determining the probability of a first spell of UI, and then through it to subsequent spells. The objective of the analysis is to examine the causal influence of parental use of UI on the incidence of a first and subsequent spells of UI, as highlighted by the dashed arrow in Figure 1 labelled "social capital." This term is used in the sense of Becker (1996, p. 4) as a catch-all to represent "the influence of past actions by peers and others in an individual's social network...." This initial capital stock is an important precondition in the model of rational addiction put forward by Becker and Murphy (1988), but its determinants are left outside of the frame of their analysis. However, the term is sufficiently broad to be consistent with a number of interpretations. It might, for example, be viewed as "social learning" in the sense of Ellison and Fudenberg (1993, 1995) and used by Lemieux and MacLeod if the family is the main locus of information about the labour market; or it could reflect the intergenerational transmission of work ethic as studied by Mulligan (1996); or of time preference as hypothesized by Becker and Mulligan (1997); or most generally as the impact of parents as role models and the erosion of any stigma to the receipt of transfer payments.

The important point, however, is that there does not appear to be any substantive research on this topic in relation to UI programs. O'Neill and Sweetman (1998) and

insignificant and in fact negative for those living east of the Ottawa River. See Lemieux and MacLeod (1998, tables 4A and 5A). This is opposite the conjecture made by Lindbeck cited earlier. In addition, May and Hollett (1995) note anecdotally that attitudes toward the receipt of government transfers in Newfoundland are changing among the young:

[t] here is ... growing concern that being on welfare is becoming more socially acceptable among young people ... as they increasingly have to turn to that system. One can see a parallel with the UI system since older workers often pride themselves as not having been on UI-that is, on not having been dependent on government assistance. Clearly, the UI program has changed people's opinions about what behavior [sic] is acceptable (p. 60).

They suggest the cause has to do with the generosity of the program and its influence on educational and occupational decisions. 
Österbacka (1999) use respectively British and Finnish data to examine intergenerational patterns in unemployment. But they do not make explicit reference to the role of UI. A similar analysis is offered by Soidre (1999) for Sweden. She finds that the unemployment experience of parents influence children by increasing the risk of becoming unemployed, of staying unemployed longer, and of experiencing repeated unemployment spells. Corak and Heisz (1998) use Canadian data to examine the correlates of the intergenerational transmission of income and find that the composition of parental income, not just the level, matters in determining the incomes of the offspring. In particular, children whose parents collected UI end up earning less as adults. They do not have a definitive explanation for this, but suggest that it most likely reflects the intergenerational transmission of occupation, as described for example in Ornstein (1998). This underscores, once again, the importance of recognizing the role of other familial background variables in order to isolate the true impact of parental UI use. The remaining parts of Figure 1 illustrate the possibility that a parent's use of UI will be correlated with a child's future use if there is a tendency for children to work in the same types of jobs as their parents, or in the same industries or firms, or to live in the same regions.

Our objective is related to a number of studies dealing with the intergenerational transmission of social assistance (AFDC) in the United States. This literature is related to the debate over the existence of an "underclass" in U.S. society, and is concerned with the degree to which a mother's use of social assistance influences a daughter's marital and fertility choices, and causes her to also rely on assistance. The conclusions as to the independent role played by a parent's receipt of transfer payments on the longer-term outcomes of children are varied. Antel (1992, p. 467) finds that "a 
mother's welfare participation is found to increase her daughter's subsequent welfare dependency." But Levine and Zimmerman (1996, p.2) find "that at least three-quarters, and perhaps all, of the correlation in welfare participation across generations can be attributed to the expected intergenerational correlation in income and other family characteristics. That is, the correlation in AFDC receipt across generations represents not a welfare trap, but rather a poverty trap." (See also Mulligan (1996), Gottschalk (1996), Gottschalk, McLanahan, and Sandefur (1994), but also Duclos, Fortin, and Rouleau (1999) who use Canadian administrative data for the province of Quebec and Stenberg (2000) who examines Swedish data.) The findings, as many of these analysts are aware, may be influenced by how long and at what point in the lifecycle the child's outcomes are observed (parents and children should be observed over as many years as possible in order to develop an accurate picture of their permanent labour market status and use of transfer payments), and the manner in which unobservables are controlled.

In light of the existing literature, our approach is two-fold. First, we model how long it takes for an individual to collect UI for the first time, paying particular attention to the influence of parental UI receipt and controlling for observables and unobservables. The use of event-history methods relies on Gottschalk (1996) and McLanahan (1988), and involves following individuals from the age of 16 when they first become eligible to work (and therefore to receive UI) until the time of their first claim. In this way individuals are observed for a possibly extended period of time, and the time-varying nature of the co-variates - specifically parental UI use-is incorporated into the model. We imagine this as the first step in a recursive process that leads to a higher probability of subsequent claims, which may then be influenced both by previous parental UI use 
(social capital) and by the fact of having had a spell in the past (individual learning).

Accordingly, the entire sequence of UI spells experienced over an extended period of time is then modelled in the manner of Lemieux and MacLeod (1998), but with an attempt to discern the relative roles of social capital and individual learning by including controls for both past parental and individual use of UI.

\section{NATURE OF THE DATA AND METHODOLOGY}

The analysis is based on administrative records associated with the income tax systems in the two countries. The Canadian data are organized as a panel data set created from the income tax records of a group of men born between 1963 and 1966, who could be linked to a parent when they were between the ages of 16 and 19 years. The family linkages are produced as a part of the construction of the T1 Family File (T1FF) by Statistics Canada and require that the individuals file an income tax return at least once while still at home. ${ }^{4}$ The first year in which income tax records are available in machine readable form is 1978, while the most recently available data is for 1997. Information on the children is retained for the years when they are between 15 and 31 years of age. Thus, the oldest members of the cohort under study are 15 in 1978 while the youngest are 31 in 1997. Information on the parents is used as appropriate throughout the 1978 to 1997 period.

\footnotetext{
${ }^{4}$ A variety of matching strategies are employed to identify family members. Couples (including spouses and common law couples) are linked using Social Insurance Numbers (SINs) when they are indicated on the $\mathrm{T} 1$ form, as well as name and address information. ( $\mathrm{T} 1 \mathrm{forms}$ are the main annual tax returns filed by individuals in Canada, and the T1FF incorporates the universe of tax filers.) Children are matched to their parents using name and address fields. See Harris and Lucaciu (1994) for more details on the construction of the T1FF. Versions of the same data used here have also been employed by Corak and Heisz (1998, 1999). In particular, Corak and Heisz (1999) explore some of the data quality and sample selection issues that arise, and also offer some comparisons to survey data.
} 
The analysis is based on a one-in-100 sample. ${ }^{5}$ In addition, to be included in the sample individuals must have filed an income tax form at least once between the ages of 26 and 31 years. The final analysis sample consists of 100,795 observations on 6,308 individuals. $^{6}$

The Swedish data are developed in a similar way. A panel data set is built using a one percent sample from the Register of Total Population from 1978 to 1995. Parents are identified and matched to children by means of central registers. These include information for each individual having formal guardianship of a child, usually the biological parents but also including parents who have adopted. ${ }^{7}$ The children are between 15 and 29 years of age. Children and parents are observed each year between 1978 and 1995 even if they have not paid any income tax in a particular year. The analysis sample consists of 55,650 observations on 3,835 individuals.

Information on the receipt of UI benefits, either by the parent or the child, is determined on the basis of whether any UI income is claimed for the year in question. Binary indicators of the presence of any amount of UI are derived for each year the individual is observed. No distinction is made in the Swedish data between insurance benefits and KAS payments. Table 1 offers a rough illustration of the degree of intergenerational correlation of UI receipt in these data by cross-tabulating the sons

\footnotetext{
${ }^{5}$ The reduction in sample size is done to ease the computational burden. Individuals are selected according to a randomly chosen last digits of their parents' SINs.

${ }^{6}$ The panel is not perfectly balanced because observations for the years in which some individuals lived in either the Yukon and Northwest Territories are excluded. This is done because one of the co-variates used in the modelling exercise, the unemployment rate, is not available for these regions of the country. This involves only 13 of the 6,308 individuals. Thus $99.48 \%$ of the sample has observations for each of the 16 years between the ages 16 and 31 . The minimum number of years in which any one individual is observed is four.

${ }^{7}$ The Swedish data also contain information on step-parents. For comparability with the Canadian data we consider the step-parent to be the father if the child is not living with the biological father.
} 
according to whether they experience UI income at least once at any time with information on their fathers. In Canada, the minority of sons (about 43\%) had fathers who collected UI benefits at some point. However $81 \%$ of these individuals relied on UI. In contrast only $70 \%$ of their counterparts - those whose fathers did not collect UI-did so. This 11 percentage point difference in the incidence of UI across these two groups is the central concern of the modelling exercise. Reliance on UI is not as extensive in Sweden, but the intergenerational correlation of UI receipt is still important. Only about $26 \%$ of the sample had fathers who used UI. However, slightly more than $68 \%$ of these individuals received some UI, while about $58 \%$ of their counterparts did so, implying a 10.6 percentage point difference - a gap comparable to the Canadian.

To model the time to first claim we use discrete-time duration models in the manner of Gottschalk (1996) and McLanahan (1988), and as discussed in Jenkins (1995) and Hosmer and Lemeshow (1989, pp.238-45). The derivation of the likelihood function in event-history modelling relies upon the fact that there is a one-to-one relationship between the density function governing spell durations and the hazard function. The latter, representing the conditional probability that a spell will end at a particular point in time, $t$, given that it has lasted to $t-1$, is the cornerstone of the analysis. If $Y_{i t}$ is a binary variable defined to be equal to 0 if individual $i$ does not report receiving UI in year $t$ and 1 if he does, then the hazard rate is defined as

$$
\lambda_{i t}=\operatorname{prob}\left(Y_{i t}=1 \mid Y_{i k}=0 \text { for } k=1 \ldots t-1 ; \mathbf{X}_{\mathrm{it}}\right)
$$

where $i=1, \ldots, N$ indexes the individuals in the sample, $t=1, \ldots, T$ the years in which they are observed, and $\mathbf{X}_{\mathrm{it}}$ is a vector of covariates. $Y_{i t}$ is a discrete time random variable and the vector of these terms represents the number of years since the age of 15 that the 
individual has gone without reporting UI income. We assume that the hazard rate takes the logistic functional form so that

$$
\lambda_{i t}\left(\mathbf{X}_{\mathrm{it}}\right)=\exp \left\{\mathbf{X}_{\mathrm{it}} \boldsymbol{\beta}\right\} /\left[1+\exp \left\{\mathbf{X}_{\mathrm{it}} \boldsymbol{\beta}\right\}\right]
$$

where the $\boldsymbol{\beta}$ is a vector of parameters to be estimated. The vector $\mathbf{X}_{\mathrm{it}}$ is assumed to contain both fixed and time-varying co-variates, and in particular contains a set of interval-specific intercept terms. The contribution to the sample likelihood of each individual for which the onset of a UI spell is observed is

$$
l_{i}(\beta)=\lambda_{i}\left(X_{i}\right)^{Y_{i t}} \prod_{k=1}^{t-1}\left[1-\lambda_{i}\left(X_{i}\right)\right]^{1-Y i k}
$$

while that for those individuals who go through the period of observation without experiencing a spell is

$$
l_{i}(\beta)=\prod_{k=1}^{t}\left[1-\lambda_{i}\left(X_{i}\right)\right]^{1-Y i k}
$$

so that the full sample likelihood is the product of these terms over the $\mathrm{N}$ individuals.

This likelihood is in the form of a logistic regression in which each individual contributes $k$ terms.

In dealing with unobserved heterogeneity we follow the path pursued by Gottschalk (1996). This involves using future parental UI participation as an additional co-variate controlling for unobserved heterogeneity. ${ }^{8}$ As Gottschalk (1996, p.4) points out this requires two assumptions. The first is that timing matters: the probability of the incidence of UI use by the child in any particular year can only be influenced (in a causal sense) by events experienced by the parent in earlier (or possibly the current) year, but not by events in future years. This would not be the case if, for example, information

\footnotetext{
${ }^{8}$ Jenkins (1995, p.135) describes some of the difficulties that arise if unobserved individual heterogeneity is controlled for in this model as a random-effect.
} 
about the parent's use of the program is conveyed to the child before benefits were actually received. This seems to be an unlikely event in the current context as it would imply that the child would, upon hearing that the parent will be starting a UI claim, have to initiate a claim and receive benefits before the parent actually began receiving benefits. The second assumption is that parental behaviour influences child behaviour, but child behaviour does not influence that of the parent's. That is, children "learn" from parents, but parents do not learn from children. To some extent this may in fact happen. Or more generally we might recognize that the labour force decisions of household members are inter-related and made simultaneously in the context of a family utility function. This is more likely to be the case when the children are still living at home.

If these assumptions hold then the correlation between a child's UI participation and the father's future participation captures the impact of the unobservables. The causal impact of the father's UI behaviour is identified from the difference in the coefficients on past and future parental UI use, a larger coefficient on past use indicating that children whose parents rely on UI are also-in a causal sense—more likely to also rely on the program. If these coefficients are found not to be statistically different from one another then the entire impact of past parental UI use on the child's probability of receiving UI is due to unobserved heterogeneity. This implies that the violation of the second assumption — that parents do not learn from their children—will lend a conservative bias to our findings. If parents also learn, to some degree, from children this is likely to increase the value of the coefficient associated with future parental use, and thereby make it more difficult to uncover a statistically significant positive difference between the past and future use variables. 
The models estimated contain two time-varying covariates for parental UI use. The first is a 0-1 binary variable that takes the value of 1 if the father received UI benefits in the current or any previous year; the second is also binary variable but takes the value of 1 if the father received benefits in any future year. For this reason the child's time to first claim is modelled between the ages of 16 and 30 for Canada, and 16 to 28 for Sweden; developments during the age of 15 and 31, and during 15 and 29 are used to determine at least one year of the parent's UI status for all periods.

The modelling of the entire sequence of UI participation uses a different approach to the control for unobservables. We adopt the random effects probit model proposed by Heckman (1981a) for discrete panel data. If $\Phi($ ) represents the Normal distribution function, then the probability that an individual experiences UI in a given year is

$$
\operatorname{prob}\left(Y_{i t}=1 \mid \gamma_{i}, Y_{i t-1}, \mathbf{y}_{\mathrm{it}}, \mathbf{X}_{\mathrm{it}}\right)=\Phi\left(\gamma_{i}+\beta_{1} Y_{i t-1}+\mathbf{y}_{\mathrm{it}} \boldsymbol{\beta}_{\mathbf{2}}+\mathbf{X}_{\mathrm{it}} \boldsymbol{\beta}_{\mathbf{3}}\right) .
$$

In this case $\gamma_{i}$ is an individual specific unobservable, and $Y_{i t-l}$ is the lagged value of the indicator of an individual's UI participation. This latter variable is included in the model since the exact timing of the start and completion of a UI claim is not measured in the administrative files. All that is known is whether UI income is received at any point during the year. In many cases UI claims will be extant at the end of one year and continue into the next so that a run of two successive values of 1 does not necessarily mean that two separate claims were initiated in each year. The vector $\mathbf{y}_{\mathrm{it}}$ contains three binary variables, one representing whether the individual collected UI at any time in the past—a control for individual learning in the sense of Lemieux and MacLeod (1998)— and another representing whether the individual's father collected at any time in the 
past—a control for social capital—and the final one being their interaction. The relative importance of the coefficients on these first two variables is the major concern of the estimation. In particular, it would be interesting to know if individual learning has any influence independent of social capital in order to more clearly understand the reasons for occurrence dependence in the data. It may be that if an individual has a parent who collected UI, his own use of UI does not offer any further information about the program and hence does not raise the probability of future UI use. Finally, $\mathbf{X}_{\mathrm{it}}$ is a vector of observable covariates meant to capture other influences on the incidence of UI use as depicted in Figure 1, including family background variables.

For any particular individual the probability of observing a particular sequence of UI spells over the T years in which the individual is part of the data set is

$$
\prod_{t=1}^{T} \Phi\left(\gamma_{t}+\beta_{1} Y_{i t-1}+\mathbf{y}_{\mathbf{i t}} \boldsymbol{\beta}_{2}+\mathbf{X}_{\mathrm{it}} \boldsymbol{\beta}_{\mathbf{3}}\right)^{Y_{i t}}\left[1-\Phi\left(\gamma_{t}+\beta_{1} Y_{i t-1}+\mathbf{y}_{\mathrm{it}} \boldsymbol{\beta}_{\mathbf{2}}+\mathbf{X}_{\mathrm{it}} \boldsymbol{\beta}_{\mathbf{3}}\right)\right]^{1-Y_{i t}} .
$$

In order to obtain an estimable likelihood function it is assumed that $\gamma_{i}$ is also distributed normally and the unconditional probability of observing a particular pattern of UI receipt is given by integrating over this distribution. If $F()$ is the distribution function of the random effect this probability is

$$
\int \prod_{t=1}^{T} \Phi\left(\gamma_{t}+\beta_{1} Y_{i t-1}+\mathbf{y}_{\mathbf{i t}} \boldsymbol{\beta}_{2}+\mathbf{X}_{\mathbf{i t}} \boldsymbol{\beta}_{3}\right)^{Y_{i t}}\left[1-\Phi\left(\gamma_{i}+\beta_{1} Y_{i t-1}+\mathbf{y}_{\mathbf{i t}} \boldsymbol{\beta}_{\mathbf{2}}+\mathbf{X}_{\mathbf{i t}} \boldsymbol{\beta}_{3}\right)\right]^{1-Y i t} d F\left(\gamma_{i}\right)
$$

So that the log-likelihood to be maximized is the sum of the log of these probabilities over all individuals in the sample. ${ }^{9}$

\section{RESULTS}

\footnotetext{
${ }^{9}$ The optimization is performed using Gauss-Hermite quadrature as implemented in the STATA version 6.0 procedure xtprobit.
} 
The variables actually included in the vector $\mathbf{X}$, and the associated descriptive statistics for both of the models to be estimated, are listed in Tables 2a and 2b. Many of these are time varying. They include a group of contemporaneous individual characteristics as depicted by the solid arrows in Figure 1: age and age squared (measured in decades), marital status, an index of the generosity of the UI program, the provincial/regional unemployment rate, an indicator of whether the individual lived in a rural area (for Canada only), and a series of indicator variables for the region of residence. ${ }^{10}$

They also include a group of family background variables as depicted in the dashed arrows of Figure 1. These are not time-varying. Parental permanent income is the income earned by both parents averaged over a twenty year period in Canada and an eighteen year period in Sweden (measured in tens of thousands of dollars). This variable is included to capture the influence of the intergenerational transmission of income status. It is also an important control variable by compensating for the lack of a full set of education and occupation indicators. These latter are captured in part, and in the manner most relevant for a study of intergenerational transmission of UI in Canada, by indicators for whether the father reported any income from farming, fishing, and other selfemployment for the years during which the son was 15 and 16. If there is an intergenerational transmission of occupation then given that farmers and the self-

\footnotetext{
${ }^{10}$ In Canada the UI index varies over time and provinces, and is a function of the number of weeks of work required to establish eligibility, the maximum duration of benefits, and the replacement rate. In Sweden, the index is an indicator variable that takes the value of 1 beginning in 1993, and reflecting the changes in the replacement rate introduced in that year. The rural residence indicator is a 0-1 binary variable defined on the basis of the second digit of the postal code. If this digit is zero the address is considered to be "rural" postal delivery route. As such this variable is determined by Canada Post for administrative reasons. As mentioned, years in which the individual lived in the Yukon or the Northwest Territories are excluded from the analysis because an unemployment rate was not available for these reasons. Region of residence is based on the first digit of the postal code and offers, in some cases, sub-provincial information. In particular, the metropolitan areas of Toronto and Montreal are distinguished as are various regions in Quebec and Ontario.
} 
employed are not eligible for UI, there may be less of a tendency for individuals whose fathers worked in these fields to collect UI. ${ }^{11}$ The exception to this are the sons of selfemployed fishers, who may be more inclined to receive UI. A self-employment indicator is also used in the Swedish data. However, it should be noted that these variables may not have the same impact in Sweden since the self-employed and farmers are entitled to UI after a three month qualifying period.

This set of family background variables includes an indicator of whether the father reported any income from assets when the individual was 15 or 16 . In Sweden these are subdivided according to whether the asset income is positive or negative during the years in question. Corak and Heisz (1998) find information of this kind to be a very important correlate of the intergenerational transmission of incomes, and suggest that it is a proxy for unobservables associated with time preference. Becker and Mulligan (1997) offer a more detailed analysis of this in the context of how time preference is passed on intergenerationally.

The final set of variables control for the possibility that individuals are likely to live in the same regions they grew up in as children: an indicator of rural residence at the age of 15 and the region of residence. For Canada these are derived from the postal codes of the parents for the appropriate year. There is no indicator of rural residence available in the Swedish data, and only region of residence at 15 years of age is controlled for.

A summary of the logit estimates of the hazard function is offered in Tables $3 \mathrm{a}$ and $3 \mathrm{~b}$ for a series of models in which a successively larger and larger set of covariates is included. Consider, first, the results using the Canadian data in Table 3a. The focus is on

\footnotetext{
${ }^{11}$ Dunn and Holtz-Eakin (1996), for example, describe the intergenerational transmission of selfemployment status in the United States.
} 
the estimates of the coefficients associated with parental past and future UI use in the first two rows of the table, and the p-value of the significance test of their equality in the third row. (All of the estimates of parental past and future UI are statistically significant, having associated p-values of less than 0.001.) The first model estimated includes only controls for past parental UI participation and a series of 0-1 indicators for the age of the son; the second model adds future parental UI participation to this, namely the control for unobservables. The coefficient on past parental use falls from 0.410 to 0.338 (about 18\%) when future parental use is added, but remains statistically different from the coefficient associated with future parental use. These estimates remain essentially unchanged as more and more controls for the contemporaneous characteristics of the individual are included in the model. All of these additional controls are individually statistically significant, with the exception of the UI generosity index, and as a group improve the fit of the model. They do not, however, change the magnitude of the past and future parental UI coefficient estimates or the relationship between them: in model (2), controlling only for age, past parental UI use is—at 0.34 -twice the magnitude of future parental UI use; in model (7), with the full set of contemporaneous controls, it remains-at 0.32-about twice as large. This changes somewhat once variables controlling for family background are included in the model. In particular, the addition of parental permanent income in column (8) lowers the parental past UI use coefficient to about 0.25 and the future use coefficient slightly to about 0.14 , while the addition of the remaining variables in columns (9), (10), and (11) does not lead to any further appreciable changes. The marginal significance level of the t-test of parameter equality rises to about 0.10 . All of the additional variables are statistically significant, with the exception of those for the 
contemporaneous region of residence, many of which seem to lose their significance once region of residence at age 15 is included in the model. ${ }^{12}$ Given that the analysis focuses on time to first spell from the age of 16 it is perhaps not surprising that the impact of the region of residence at age 15 works through the contemporaneous region of residence. There is likely to be a great deal of similarity between these measures for a large fraction of the time the spells are studied. Thus, the results from the preferred model of this exercise are presented in column (12). It includes all of the available co-variates with the exception of contemporaneous region of residence. In this model, the null hypothesis that the influence of past and future parental UI use are the same is incorrectly rejected with a probability of $8.5 \%$.

Somewhat different results are obtained with the Swedish data (see Table 3b). The coefficient associated with the father's past UI use in model (1) has roughly the same general magnitude as that obtained with Canadian data, and falls about $14 \%$ (from 0.465 to 0.400 ) when father's future use is added. Even so, in model (2) the two coefficients are statistically different with a p-value of 0.115 . With the addition of extra variables this $\mathrm{p}$ value increases slightly to 0.163 in column (7), but jumps markedly—to 0.456 - once parental permanent income is added in column (8). In the full model described in column (11) the coefficients are 0.240 and 0.182 , and the marginal significance level for the test of equality is 0.538 . Quite clearly, the null hypothesis that the two coefficients are the same cannot be rejected at any reasonable significance level. The implication is that we

\footnotetext{
${ }^{12} \mathrm{~A}$ Wald test for the significance of the region of residence indicators in model (10) yields a $\chi^{2}(15)$ value of 20.7, with an associated p-value of 0.146. A similar test for the joint significance of the region of residence at age 15 variables yields a $\chi^{2}(17)$ of 137.6 with a $p$-value of less than 0.0001 .
} 
are not able to reject the possibility that in the Swedish data the impact of family background on the time to a first UI claim is entirely spurious.

The complete set of Canadian results for model (12) and Swedish results for model (11) are presented in Tables $4 \mathrm{a}$ and $4 \mathrm{~b}$, along with an estimate of the associated marginal impact of each variable. ${ }^{13}$ In Canada, being married lowers the probability of starting a spell of UI, while higher provincial unemployment rates and living in a rural area increases it. In Sweden, being married has no statistically significant influence on the probability of starting a UI spell. UI generosity has a statistically significant negative coefficient, but this is the expected sign as it is defined as being equal to one beginning in 1993 when the replacement rate declined from $90 \%$ to $80 \%$. Family background variables all seem to work in a plausible way in both countries: higher parental permanent income lowering the chances that a son will experience a first claim; the presence of parental farming, and (positive) asset income doing the same; and the presence of parental fishing income increasing the chances of starting a claim in Canada. The impact of this latter variable is particularly striking. If a father claimed to have income from fishing when the son was 15 or 16 , the son's chances of starting a first claim—all other things equal—are almost 5 percentage points higher.

These results are used to derive estimates of the impact of social capital on the hazard rates at the point of sample means from the age of 16 onward. These are offered in Figures $2 \mathrm{a}$ and $2 \mathrm{~b}$. The overall patterns are roughly the same in the two countries: the

\footnotetext{
${ }^{13}$ The derivation of the marginal effect of the binary co-variates in this table is approximate and calculated as $\mathcal{L}(\mathbf{X} \boldsymbol{\beta})[1-\mathcal{L}(\mathbf{X} \boldsymbol{\beta})] \boldsymbol{\beta}$ where $\mathcal{L}()$ represents the logistic probability distribution, $\mathbf{X}$ the sample averages of the co-variates (binary co-variates being set to their sample proportions), and $\boldsymbol{\beta}$ the vector of estimated coefficients. This is usually a close approximation to estimating the difference between the probabilities of setting the indicator to one and to zero. See Greene (1997, pp.875-79). The same caveat applies to the discussion of the marginal effects from the probit model discussed below in the context of tables $7 \mathrm{a}$ and $7 \mathrm{~b}$.
} 
hazard rate rises sharply during the teen years and peaks at 20 to 21 years of age, then falls and plateaus during the early to mid 20s, before falling during the late 20 s. The Canadian estimates typically lie above those for Sweden throughout most of the age period being examined. However, the hazard rate at age 18 is actually higher in Sweden. By age 28 the hazard rates are about the same in the two countries.

The three lines in these figures refer to the estimated hazard rates when: (1) the indicator variables for past and future parental UI use are both set to zero; (2) when only the future use variable is set to one; (3) and when only the past use variable is set to one. The difference between (1) and (2) represents the impact of unobservables, while that between (2) and (3) represents the causal impact of social capital.

In Canada, the hazard rate associated with having a father who had used UI at any point in the past is higher than that associated with having one who had not used UI at all, the difference being greatest between the ages of 19 and 22, and peaking at the age of 20. The conditional probability of beginning a spell of insured unemployment is about three percentage points higher during these years for those whose fathers used UI in the past compared to those whose fathers never used the program, but about half of this is due to the influence of unobservables. ${ }^{14}$

Figure $2 \mathrm{~b}$ for Sweden shows an equivalent pattern with the conditional probability of beginning a spell of insured unemployment peaking at 20 to 21 years of age. The differences between those whose fathers used UI and those whose fathers didn't are also greatest during these years. However, this difference of about two percentage points is almost entirely due to unobservables. In fact, as the results in column (11) of

\footnotetext{
${ }^{14}$ A model in which the coefficient on father's past UI use is allowed to vary with age was also estimated, but did not lead to statistically significant results.
} 
Table $3 b$ suggest, the observed difference between the two upper lines is not statistically significant.

These findings are detailed in Tables $5 \mathrm{a}$ and $5 \mathrm{~b}$, where both the hazard and survivor rates associated with model (12) of Table 3a for Canada, and model (11) of Table $3 b$ for Sweden are presented. The estimates of the survivor function from the Canadian data suggest that only about $24 \%$ of individuals whose father collected UI at some point in the past will make it to the age of 30 without also collecting UI, while over $32 \%$ of their counterparts whose fathers did not collect UI do so. This eight percentage point difference is due about equally to unobservables and to the causal influence of parental UI use.

In Sweden a higher proportion of the sample makes it to the age of 28 without ever collecting UI: $47 \%$ of those with fathers who did not collect, and $38 \%$ of those whose fathers did. ${ }^{15}$ This nine percentage point difference is due almost entirely to unobservables suggesting that in Sweden the influence of social capital—as reflected in parental UI use-does not seem to have a major role in determining the onset of a first UI spell for the son.

The possibility that a first spell of UI kicks off a long-lasting process by raising the chances of repeated UI use in the future is explored in the random-effects probit model. The central estimates of this model are presented in Tables 6a and 6b. Once again a series of models are presented with successively larger sets of co-variates. The model presented in columns (1) contain a single co-variate, the indicator of past individual UI use. For Canada, the estimated probit coefficient of 0.31 falls only slightly, to 0.28 , when

\footnotetext{
${ }^{15}$ For Canada the comparable figures at age 28 are $35 \%$ and $26 \%$ respectively.
} 
the indicator of past parental use is added to the model. In this model individual learning dominates social learning. However, the inclusion of the interaction of these terms in column (3) leads to a finding that can be interpreted to suggest that individual learning is a lot less important and dominated by social learning. Having had a father who collected UI in the past reduces the independent impact of having made a past claim by about half. In other words, the impact of past claims on the probability of future claims is muted by having had a parent who collected. This result is much stronger when controls for age are included in the model. The result in column (4) shows that individual past use in models (1) through (3) is in large part a proxy for age, the coefficient being only a third in magnitude and completely dominated by the interaction term with parental use. In this model individual learning raises the incidence of UI only if the parent has not received UI. The addition of co-variates associated with the individual's region of residence (the unemployment rate, the UI generosity, and the rural and region controls) lowers the value of the social learning coefficient slightly, but it essentially remains at about 0.23 or 0.24 with the individual learning coefficient about six-tenths to seven-tenths the magnitude.

The addition of familial background controls, most notably the parental permanent income, reduces both coefficients a little, without changing the relative magnitudes appreciably. In this model, the indicators for the region of residence continue to play a statistically significant role even when the region of residence as a child is entered into the model. In column (13) the results from the complete model are offered. In this model the null hypothesis that the individual learning and social capital coefficients are equal would be falsely rejected with a probability of 0.0256 . The null that the sum of the individual learning and the interaction term are equal to zero has a higher 
associated p-value, 0.0786. It is possible that individual learning continues to raise the probability of experiencing a UI spell in the presence of parental past use but the effect is small, the best estimate of the impact being 0.04 .

The Swedish results are different: individual learning dominates social learning. The coefficient for individual past use in column (1) at 0.441 is higher than the estimate from the Canadian data, and essentially remains unchanged as controls for the father's past use and the interaction of the two variables are added to the model. Indeed, the interaction term is never statistically significant. Once controls for age are included in the model the estimated coefficient for individual past use is about 0.3 , and remains essentially unchanged with the addition of controls for other individual characteristics. At the same time the estimate for father's past use falls with each additional individual characteristic added to the model, taking the value of 0.18 in model (9). Once family background variables are added both coefficients fall in value, the control for individual learning not falling as much as that for social learning. The values of these coefficients in the complete model are 0.264 and 0.145 . These are statistically different with a marginal probability level of 0.001 .

The complete results from this model as well as the associated marginal effects is presented for both countries in Tables $7 \mathrm{a}$ and $7 \mathrm{~b}$. In Canada, individual past use of the program raises the probability of future use by 1.9 percentage points. However, if the father has used UI in the past the probability rises by 2.8 percentage points and leads the impact of individual past use to fall to only about 0.7 percentage points $(0.0193-0.0127)$. In Sweden, on the other hand, individual past use raises the probability of future use by 4.6 percentage points; if the father used the program in the past the probability of future 
use increases by a further 2.5 percentage points. The remaining results mirror the patterns presented in Tables $4 \mathrm{a}$ and $4 \mathrm{~b}$ for the time to a first claim. Most notably in Canada, the sons of fishers have a nine percentage point higher chance of collecting UI benfits.

\section{CONCLUSION}

Our comparative analysis of longitudinal patterns in the use of UI in Canada and Sweden has two parts. We analyze, using discrete time duration models, the time to a first UI spell paying particular attention to the influence of father's UI use, and controlling for unobservable heterogeneity by relying on the timing of the father's UI spells. We also model the entire sequence of UI use over a 12 to 15 year period (beginning in the late 1970s) using random effects probit models, and focusing upon the relative role of parental background and individual past use in determining the probability of receiving UI. In this way we seek to uncover the degree to which parental background launches individuals down a path of repeated interaction with UI, as well as the relative importance of past individual interaction with the program on future use when parental background is also being controlled.

The analysis reveals, firstly, that the incidence of UI use was high among young adult men in both Canada and Sweden. About $75 \%$ of young Canadian men relied on the program at least once by the age of 30 ; slightly more than $60 \%$ of Swedes did so. However, there are substantial differences in these proportions between those whose fathers used UI at some point, and those whose fathers did not: over $80 \%$ of young Canadian men whose fathers collected UI also collected, versus about $70 \%$ of those whose fathers did not; in Sweden the comparable figures are about $70 \%$ and $58 \%$. Our 
major objective is to examine the extent to which these differences reflect a correlation in characteristics (both observed and unobserved) between father and son that influence UI use, and the extent to which they reflect a relationship in which a father's use of UI somehow influences the son's probability of relying on the program.

In Canada, the incidence of a first UI claim is influenced by family background. Young men whose fathers collected UI in the past generally begin their first UI claim sooner. Parental background also heightens the chances of repeated UI use regardless of individual past history. Individual learning about the program is significant only if the individual has no family background of UI use. In Sweden, the first experience is not influenced in a causal way by family background. However, once the individual relies on the program — and those from lower income families are more likely to do so-individual learning becomes a very important influence on the probability of experiencing another claim. For example, we find that in Canada the roughly 10 percentage point difference in UI use between those whose fathers had received UI and those fathers did not, about a third can be accounted for by differences in observable characteristics, and a third by differences in unobservables. The remaining third is attributed to social learning related to family background. Further, past individual experience with UI will raise the probability of future use (by about 2 percentage points) but only for individuals whose fathers did not use UI. When there is a parental history of UI use the probability of a future claim is higher (by about 3 percentage points) and individual past use no longer has an important influence. In contrast, the correlation between father and son use of UI in Sweden is entirely due to the correlation of observable and unobservable influences. The probability of beginning a claim during the late twenties, conditional on not having 
used it up to that time, is about the same in the two countries, but generally young Swedish men are less likely to begin a UI claim than Canadian men. The only exception to this occurs at about the age of 18 when they are more likely to do so. Further, while subsequent use of the program is higher if fathers used the program in the past, individual past use has a much stronger influence on future use. The chances of relying on UI in any given year are almost 5 percentage points higher in Sweden if the individual has used it in the past. Individual learning — not social learning—is the dominant influence in determining repeated interaction with the Swedish program. 


\section{BIBLIOGRAPHY}

ACKUM AGELL, Susanne, Anders Björklund, and Anders Harkman (1995).

"Unemployment Insurance, Labour Market Programmes and Repeated Unemployment in Sweden.” Swedish Economic Policy Review. Vol.2, 101-128.

ANDERSON, Patricia M. and Bruce D. Meyer (1993). “The Unemployment Insurance Payroll Tax and Interindustry and Interfirm subsidies.” In James M. Poterba (editor). Tax Policy and the Economy. Volume 7. Cambridge, Massachusetts: National Bureau of Economic Research and MIT Press.

ANTEL, John J. (1992). “The Intergenerational Transfer of Welfare Dependency: Some Statistical Evidence." Review of Economics and Statistics. Vol. 74, No.3 (August) 467-73.

ATKINSON, A.B. and John Micklewright (1991). "Unemployment Compensation and Labour Market Transitions: A Critical Review.” Journal of Economic Literature. Vol. 29 (December) 1679-1727.

BECKER, Gary S. (1996). Accounting for Tastes. Cambridge, Massachusetts: Harvard University Press.

BECKER, Gary S. and Casey B. Mulligan (1997). “The Endogenous Determination of Time Preference." Quarterly Journal of Economics. Vol. 112, No. 3 (August) 729-58.

BECKER , Gary S. and Kevin M. Murphy (1988). “A Theory of Rational Addiction.” Journal of Political Economy. Vol. 96, No. 4 675-700. Reprinted as Chapter 3 in Becker (1996). 
van den BERG, Axel, Bengt Furåker, and Leif Johansson (1997). Labour Market Regimes and Patterns of Flexibility: A Sweden-Canada Comparison. Lund: Arkiv förlag.

BJÖRKLUND, A. (1991). "The Economics of Unemployment Insurance: The Case of Sweden.” In A. Björklund et al. (eds.). Labour Market Policy and Unemployment Insurance. Oxford: Clarendon Press.

CANADA (1995). Human Resources Development Canada. A $21^{\text {st }}$ Century Employment System for Canada: Guide to the Employment Insurance Legislation. Ottawa: Minister of Supply and Services Canada.

CORAK, Miles (1994). "Unemployment Insurance, Work Disincentives, and the Canadian Labor Market: An Overview." In Christopher Green, Fred Lazar, Miles Corak, and Dominique M. Gross. Unemployment Insurance: How to Make it Work. Toronto: C.D. Howe Institute.

CORAK, Miles (1993a). "Unemployment Insurance Once Again: The Incidence of Repeat Participation in the Canadian UI Program.” Canadian Public Policy. Vol. 19, No.2 (June) 162-76.

CORAK, Miles (1993b). "Is Unemployment Insurance Addictive? Evidence from the Benefit Durations of Repeat Users.” Industrial and Labor Relations Review. Vol. 47, No.1 (October) 62-72.

CORAK, Miles (1992). "Traps and Vicious Circles: A Longitudinal Analysis of Participation in the Canadian Unemployment Insurance Program." Economic Council of Canada Working Paper No. 31. Ottawa: Economic Council of Canada. 
CORAK, Miles and Andrew Heisz (1999). "The Intergenerational Earnings and Income Mobility of Canadian Men: Evidence from Longitudinal Income Tax Data." Journal of Human Resources. Vol. 34, No. 3 (Summer) 504-33.

CORAK, Miles and Andrew Heisz (1998). "How to Get Ahead in Life: Some Correlates of Intergenerational Income Mobility in Canada.” In Miles Corak (editor), Labour Markets, Social Institutions, and the Future of Canada's Children. Ottawa: Statistics Canada, Catalogue Number 89-553-xpb.

CORAK, Miles and Wendy Pyper (1995). Workers, Firms and Unemployment Insurance. Ottawa: Statistics Canada, Catalogue No. 73-505.

DUCLOS, Jean-Yves, Bernard Fortin, and Manon Rouleau (1999). "Une analyse économétrique de la dépendance inter-générationnelle à l'aide sociale." Université Laval. Unpublished.

DUNN, Thomas and Douglas Holtz-Eakin (1996). "Financial Capital, Human Capital, and the Transition to Self-Employment: Evidence from Intergenerational Links." NBER Working Paper No. 5622.

ELLISON, Glenn and Drew Fudenberg (1995). "Word-of-Mouth Communication and Social Learning." Quarterly Journal of Economics. Vol. 110, No. 1, 93-126.

ELLISON, Glenn and Drew Fudenberg (1993). "Rules of Thumb for Social Learning." Journal of Political Economy. Vol. 101, 612-43.

GREENE, William H. (1997). Econometric Analysis. Third Edition. Upper Saddle River, New Jersey: Prentice-Hall. 
GOTTSCHALK, Peter (1996). "Is the correlation in welfare participation across generations spurious?" Journal of Public Economics. Vol. 63, No. 1 (December) $1-25$.

GOTTSCHALK, Peter, Sara McLanahan, and Gary D. Sandefur (1994). “The Dynamics and Intergenerational Transmission of Poverty and Welfare Participation.” In Sheldon H. Danziger, Gary D. Sandefur and Daniel H. Weinberg (editors). Confronting Poverty: Prescriptions for Change. Cambridge Massachusetts: Harvard University Press and Russell Sage Foundation.

GUSTAFSSON, Björn and N. Anders Klevmarken (1993). "Taxes and Transfers in Sweden: Incentive Effects on Labour Supply." In Welfare and Work Incentives. New York: Oxford University Press.

HARRIS, Shelly and Daniela Lucaciu (1994). "An Overview of the T1FF Creation.” LAD Reports, Reference Number 94-24-01 v1.2. Small Areas and Administrative Data Division. Ottawa: Statistics Canada.

HECKMAN, James J. (1981a). "Statistical Models for Discrete Panel Data.” In Charles F. Manski and Daniel McFadden (editors). Structural Analysis of Discrete Data with Economic Applications. Cambridge Massachusetts: The MIT Press.

HECKMAN, James J. (1981b). "The Incidental Parameters Problem and the Problem of Initial Conditions in Estimating a Discrete Time-Discrete Data Stochastic Process.” In Charles F. Manski and Daniel McFadden (editors). Structural Analysis of Discrete Data with Economic Applications. Cambridge Massachusetts: The MIT Press. 
HECKMAN, James J. and George Borjas (1980). “Does Unemployment Cause Future Unemployment? Definitions, Questions, and Answers from a Continuous Time Model of Heterogeneity and State Dependence.” Economica. Vol. 47, No. 187 (August) 247-83.

HOSMER, David W. and Stanley Lemeshow (1989). Applied Logistic Regression. New York: John Wiley \& Sons.

JENKINS, Stephen P. (1995). "Easy Estimation Methods for Discrete-Time Duration Models." Oxford Bulletin of Economics and Statistics. Vol. 57, No. 1, 129-38,

KALBFLEISCH, John D. and Robert L. Prentice (1980). The Statistical Analysis of Failure Time Data. New York: Wiley and Sons.

LEMIEUX, Thomas and W. Bentley MacLeod (1998). "Supply Side Hysterisis: The Case of the Canadian Unemployment Insurance System.” National Bureau of Economic Research Working Paper No. 6732.

LEMIEUX, Thomas and W. Bentley MacLeod (1995). "State Dependence and Unemployment Insurance.” Technical Report No. 4. Ottawa: Human Resources Development Canada.

LEVINE, Phillip B. and David J. Zimmerman (1996). “The Intergenerational Correlation in AFDC Participation: Welfare Trap or Poverty Trap?" Institute for Research on Poverty Discussion Paper no. 1100-96.

LINDBECK, Assar (1995). "Hazardous Welfare-State Dynamics.” American Economic Review. Vol. 85, No 2 (May) 9-15.

LJUNGQVIST, Lars and Thomas J. Sargent (1998). “The European Unemployment Dilemma." Journal of Political Economy. Vol. 106 No.3, 514-50. 
MAY, Doug and Alton Hollet (1995). The Rock in a Hard Place: Atlantic Canada and the UI Trap. Toronto: C.D. Howe Institute.

McLANAHAN, Sara S. (1988). "Family Structure and Dependency: Early Transitions to Female Household Headship.” Demography. Vol. 25, No. 1 (February) 1-16.

MEYER, Bruce D. and Dan T. Rosenbaum (1996). "Repeat Use of Unemployment Insurance.” National Bureau of Economic Research Working Paper No. 5423.

MOFFIT, Robert (1983). “An Economic Model of Welfare Stigma.” American Economic Review. Vol. 73, No. 5 (December) 1023-35.

MULLIGAN, Casey B. (1996). "Work Ethic and Family Background: Some Evidence." University of Chicago, unpublished.

O’NEILL, Donal and Olive Sweetman (1998). “Intergenerational Mobility in Britain: Evidence from unemployment patters." Oxford Bulletin of Economics and Statistics. Vol. 60, No. 4 (November) 431-47.

OECD (1994). The OECD Jobs Study: Evidence and Explanations, Part II The Adjustment Potential of the Labour Market. Paris: Organisation for Economic Co-operation and Development.

ORNSTEIN, Michael (1998). "Educational and Occupational Inheritance in Canada." Institute for Social Research and Department of Sociology, York University, unpublished.

ÖSTERBACKA, Eva (1999). “The Connection Between Unemployment Among Relatives in Finland." Paper presented to the meetings of the European Society for Population Economics, Turin Italy. 
SARGENT, Timothy C. (1995). “An Index of Unemployment Insurance Disincentives.” Economic and Fiscal Policy Branch, Working Paper No. 95-10. Ottawa: Department of Finance.

SOIDRE, Tiiu (1999). “Arbetslöshet och generation - unga kvinnor och män och dera föräldrar." Arbetsmarknad \& Arbetsliv. Vol. 5, No. 2, 127-44.

STENBERG, Sten-Åke (2000). ... Journal of Marriage and the Family. February. 
Table 1 CORRELATION OF FATHER-SON UI USE IN CANADA AND SWEDEN

\begin{tabular}{|c|c|c|c|c|c|c|}
\hline \multirow[b]{3}{*}{ Sons } & \multicolumn{4}{|c|}{ Fathers } & & \\
\hline & \multicolumn{2}{|c|}{ Did Not Collect UI } & \multicolumn{2}{|c|}{ Collected UI } & \multicolumn{2}{|c|}{ Total } \\
\hline & Number & Per Cent & Number & Percent & Number & Percent \\
\hline \multicolumn{7}{|l|}{ 1. Canada } \\
\hline Did Not Collect UI & 1,064 & 29.7 & 516 & 18.9 & 1,580 & 25.1 \\
\hline Collected UI & 2,519 & 70.3 & 2,209 & 81.1 & 4,728 & 74.9 \\
\hline Total & 3,583 & & 2,725 & & 6,308 & \\
\hline \multicolumn{7}{|l|}{ 2. Sweden } \\
\hline Did Not Collect UI & 1198 & 42.3 & 318 & 31.7 & 1516 & 39.5 \\
\hline Collected UI & 1635 & 57.7 & 684 & 68.3 & 2319 & 60.5 \\
\hline Total & 2,833 & & 1,002 & & 3,835 & \\
\hline
\end{tabular}


Table 2a

DESCRIPTIVE STATISTICS FOR THE ANALYSES OF TIME TO FIRST SPELL AND LONGITUDINAL PATTERNS IN UI USE: CANADA

\begin{tabular}{|c|c|c|c|c|}
\hline \multirow[b]{3}{*}{ Individual Used UI } & \multicolumn{2}{|c|}{ Time to First UI Spell } & \multicolumn{2}{|c|}{ Longitudinal Patterns in UI Use } \\
\hline & \multirow[t]{2}{*}{ Mean } & Standard Deviation & \multicolumn{2}{|c|}{ Mean $\quad$ Standard Deviation } \\
\hline & & & 0.2161 & \\
\hline Individual Used UI in Past & & & 0.4324 & \\
\hline Father Used UI in Past & 0.2390 & & 0.3195 & \\
\hline Individual and Father Used UI in Past & & & 0.1838 & \\
\hline Lagged Dependent Variable & & & 0.2042 & \\
\hline Father Used UI in the Future & 0.2897 & & & \\
\hline Age (in decades) & & & 2.350 & 0.4610 \\
\hline Age Squared & & & 5.734 & 2.175 \\
\hline Married & 0.1323 & & 0.2314 & \\
\hline Provincial UI Generosity Index & 1.035 & 0.2175 & 0.9855 & 0.2324 \\
\hline Provincial Unemployment Rate & 9.6 & 2.8 & 9.8 & 2.8 \\
\hline Rural Residence & 0.2110 & & 0.2326 & \\
\hline \multicolumn{5}{|c|}{ Region of Residence (Toronto Metropolitan as reference case) } \\
\hline Newfoundland & 0.0167 & & 0.0220 & \\
\hline Nova Scotia & 0.0347 & & 0.0370 & \\
\hline Prince Edward Island & 0.0037 & & 0.0048 & \\
\hline New Brunswick & 0.0251 & & 0.0295 & \\
\hline Quebec East & 0.0706 & & 0.0769 & \\
\hline Montreal Metropolitan & 0.0784 & & 0.0765 & \\
\hline Quebec West & 0.0867 & & 0.1004 & \\
\hline Eastern Ontario & 0.0708 & & 0.0633 & \\
\hline Central Ontario & 0.1226 & & 0.1129 & \\
\hline South-western Ontario & 0.0864 & & 0.0839 & \\
\hline Northern Ontario & 0.0313 & & 0.0319 & \\
\hline Manitoba & 0.0444 & & 0.0425 & \\
\hline Saskatchewan & 0.0400 & & 0.0412 & \\
\hline Alberta & 0.0887 & & 0.0919 & \\
\hline British Columbia & 0.0877 & & 0.0973 & \\
\hline \multicolumn{5}{|l|}{ Family Background } \\
\hline Parental Permanent Income $(\$ 10,000 \mathrm{~s})$ & 3.9577 & 7.2931 & 3.4947 & 5.8719 \\
\hline Farming Income & 0.0765 & & 0.0774 & \\
\hline Fishing Income & 0.00388 & & 0.008532 & \\
\hline Self-Employment Income & 0.1506 & & 0.1457 & \\
\hline Asset Income & 0.6240 & & 0.5877 & \\
\hline Rural Residence at Age 15 & 0.2386 & & 0.2766 & \\
\hline \multicolumn{5}{|c|}{ Region of Residence at Age 15 (Toronto Metropolitan as reference case) } \\
\hline Newfoundland & 0.0180 & & 0.0269 & \\
\hline Nova Scotia & 0.0350 & & 0.0385 & \\
\hline Prince Edward Island & 0.0039 & & 0.0057 & \\
\hline New Brunswick & 0.0266 & & 0.0319 & \\
\hline Quebec East & 0.0733 & & 0.0818 & \\
\hline Montreal Metropolitan & 0.0815 & & 0.0795 & \\
\hline Quebec West & 0.0882 & & 0.0992 & \\
\hline Eastern Ontario & 0.0710 & & 0.0640 & \\
\hline Central Ontario & 0.1119 & & 0.0996 & \\
\hline South-western Ontario & 0.0856 & & 0.0833 & \\
\hline Northern Ontario & 0.0355 & & 0.0356 & \\
\hline Manitoba & 0.0478 & & 0.0468 & \\
\hline Saskatchewan & 0.0435 & & 0.0464 & \\
\hline Alberta & 0.0828 & & 0.0838 & \\
\hline British Columbia & 0.0832 & & 0.0883 & \\
\hline Northwest Territories & 0.0004 & & 0.0003 & \\
\hline Yukon & 0.0001 & & 0.0001 & \\
\hline Number of person-years & 57,208 & & 100,795 & \\
\hline Number of persons & 6,308 & & 6,308 & \\
\hline
\end{tabular}

Parental Permanent Income is measured in constant 1986 dollars, but in the econometric analysis is standarized to have mean zero and standard deviation one. The Time to First UI Spell analysis also includes a series of age-specific indicator variables. The sample proportions of these are:

16 years, $0.1101 ; 17$ years, $0.1095 ; 18$ years, $0.1075 ; 19$ years, $0.1015 ; 20$ years, $0.0877 ; 21$ years, $0.0741 ; 22$ years, $0.0633 ; 23$ years, $0.0545 ; 24$ years,

$0.0486 ; 25$ years, $0.0440 ; 26$ years, $0.0402 ; 27$ years, $0.0364 ; 28$ years, $0.0334 ; 29$ years, $0.0311 ; 30$ years, 0.0295 . 
Table $2 b$

DESCRIPTIVE STATISTICS FOR THE ANALYSES OF TIME TO FIRST SPELL AND LONGITUDINAL PATTERNS IN UI USE: SWEDEN

\begin{tabular}{|c|c|c|c|c|}
\hline \multirow[b]{3}{*}{ Individual Used UI } & \multicolumn{2}{|c|}{ Time to First UI Spell } & \multicolumn{2}{|c|}{ Longitudinal Patterns in UI Use } \\
\hline & Mean & Standard Deviation & Mean & Standard Deviation \\
\hline & & & 0.161 & \\
\hline Individual Used UI in Past & & & 0.312 & \\
\hline Father Used UI in Past & 0.125 & & 0.162 & \\
\hline Individual and Father Used UI in Past & & & 0.076 & \\
\hline Lagged Dependent Variable & & & 0.144 & \\
\hline Father Used UI in the Future & 0.148 & & 0.141 & \\
\hline Age (in decades) & & & 2.284 & 0.434 \\
\hline Age Squared & & & 5.403 & 2.011 \\
\hline Married & 0.062 & & 0.090 & \\
\hline UI Generosity Index dummy & 0.132 & & 0.207 & \\
\hline Unemployment Rate & 6.887 & 3.640 & 7. 903 & 4.267 \\
\hline \multicolumn{5}{|l|}{ Region of Residence } \\
\hline Stockholm county & 0.219 & & 0.186 & \\
\hline Göteborg county & 0.095 & & 0.090 & \\
\hline Malmöhus county & 0.097 & & 0.097 & \\
\hline Forest counties & 0.132 & & 0.162 & \\
\hline Other counties & 0.456 & & 0.465 & \\
\hline \multicolumn{5}{|l|}{ Family Background } \\
\hline Parental Permanent Income & 5.1017 & 2.8459 & 4.9034 & 2.6770 \\
\hline Farming Income & 0.071 & & 0.069 & \\
\hline Self-Employment Income & 0.117 & & 0.117 & \\
\hline Positive asset Income & 0.233 & & 0.213 & \\
\hline Negative asset income & 0.681 & & 0.698 & \\
\hline \multicolumn{5}{|l|}{ Region of Residence at age 15} \\
\hline Stockholm county & 0.202 & & 0.167 & \\
\hline Göteborg county & 0.093 & & 0.085 & \\
\hline Malmöhus county & 0.095 & & 0.094 & \\
\hline Forest counties & 0.142 & & 0.173 & \\
\hline Other counties & 0.468 & & 0.480 & \\
\hline Number of person years & 38295 & & 55650 & \\
\hline Number of persons & 3835 & & 3835 & \\
\hline
\end{tabular}

In the econometric analysis parental permanent income is standarized to have mean zero and standard deviation one.

The Time to First UI Spell analysis also includes a series of age-specific indicator variables. The sample proportions of these are:

16 years, $0.0741 ; 17$ years, $0.0740 ; 18$ years, $0.0742 ; 19$ years, $0.0740 ; 20$ years, $0.0741 ; 21$ years, $0.0740 ; 22$ years, $0.0739 ; 23$ years, $0.0740 ; 24$ years,

$0.0739 ; 25$ years, $0.0739 ; 26$ years, $0.0740 ; 27$ years, $0.0741 ; 28$ years, 0.0623 . 
Table $3 \mathrm{a}$

TIME TO FIRST UI USE FOR CANADIAN MEN: SUMMARY OF LOGIT ESTIAMTES OF THE HAZARD FUNCTION

\begin{tabular}{|c|c|c|c|c|c|c|c|c|c|c|c|c|}
\hline & (1) & (2) & (3) & (4) & (5) & (6) & (7) & (8) & (9) & (10) & (11) & (12) \\
\hline Father Used UI in the Past & 0.410 & 0.338 & 0.340 & 0.334 & 0.327 & 0.313 & 0.321 & 0.245 & 0.246 & 0.244 & 0.245 & 0.248 \\
\hline Father Used UI in the Future & & 0.172 & 0.173 & 0.155 & 0.149 & 0.151 & 0.153 & 0.139 & 0.137 & 0.137 & 0.137 & 0.135 \\
\hline P-value for test of equality & & 0.009 & 0.009 & 0.005 & 0.005 & 0.011 & 0.009 & 0.104 & 0.093 & 0.102 & 0.102 & 0.085 \\
\hline \multicolumn{13}{|l|}{ Other Individual Controls } \\
\hline Age & $\checkmark$ & $\checkmark$ & $\checkmark$ & $\checkmark$ & $\checkmark$ & $\checkmark$ & $\checkmark$ & $\checkmark$ & $\checkmark$ & $\checkmark$ & $\checkmark$ & $\checkmark$ \\
\hline Marital Status & & & $\checkmark$ & $\checkmark$ & $\checkmark$ & $\checkmark$ & $\checkmark$ & $\checkmark$ & $\checkmark$ & $\checkmark$ & $\checkmark$ & $\checkmark$ \\
\hline Provincial UI Generosity Index & & & & $\checkmark$ & $\checkmark$ & $\checkmark$ & $\checkmark$ & $\checkmark$ & $\checkmark$ & $\checkmark$ & $\checkmark$ & $\checkmark$ \\
\hline Provincial Unemployment Rate & & & & & $\checkmark$ & $\checkmark$ & $\checkmark$ & $\checkmark$ & $\checkmark$ & $\checkmark$ & $\checkmark$ & $\checkmark$ \\
\hline Rural Residence & & & & & & $\checkmark$ & $\checkmark$ & $\checkmark$ & $\checkmark$ & $\checkmark$ & $\checkmark$ & $\checkmark$ \\
\hline Region of Residence & & & & & & & $\checkmark$ & $\checkmark$ & $\checkmark$ & $\checkmark$ & $\checkmark$ & \\
\hline \multicolumn{13}{|l|}{ Other Family Background Controls } \\
\hline Parental Permanent Income & & & & & & & & $\checkmark$ & $\checkmark$ & $\checkmark$ & $\checkmark$ & $\checkmark$ \\
\hline Sources of Father's Income & & & & & & & & & $\checkmark$ & $\checkmark$ & $\checkmark$ & $\checkmark$ \\
\hline Rural Residence at age 15 & & & & & & & & & & $\checkmark$ & $\checkmark$ & $\checkmark$ \\
\hline Region of Residence at age 15 & & & & & & & & & & & $\checkmark$ & $\checkmark$ \\
\hline - log likelihood & 15048.9 & 15038.5 & 15030.3 & 14952.3 & 14929.7 & 14863.8 & 14825.5 & 14743.2 & 14708.9 & 14705.8 & 14691.1 & 14702.8 \\
\hline
\end{tabular}

Reported coefficients are from a logit model of the hazard rate to first UI use, and all have a p-value less than 0.001 . The standard errors account for clustering across individuals and are robust to heteroscedasticity. Region of Residence refers to 16 provincial and sub-provincial regions defined according to the first digit of the postal code. Permanent Income refers to the average of total parental income over a twenty year period, while sources of the Father's income include indicator variables for whether the father reported income from farming, fishing self-employment or asset income when the son was 15 to 16 years of age. A Wald test for the significance of the region of residence indicators in model (11) yields a $\chi^{2}(15)$ value of 20.7 and an associated p-value of 0.146 . A similar test that the coefficients on the controls for region of residence at age 15 are jointly equal to zero yields a $\chi^{2}(17)$ statistic of 137.6 with a p-value less than 0.0001

Number of observations is 57,208 representing 6,308 individuals. 
Table $3 b$

TIME TO FIRST UI USE FOR SWEDISH MEN: SUMMARY OF LOGIT ESTIAMTES OF THE HAZARD FUNCTION

\begin{tabular}{|c|c|c|c|c|c|c|c|c|c|c|c|c|}
\hline & (1) & (2) & (3) & (4) & (5) & (6) & (7) & (8) & (9) & $(10)$ & (11) & (12) \\
\hline Father Used UI in the Past & 0.465 & 0.400 & 0.399 & 0.390 & 0.320 & & 0.318 & 0.280 & 0.240 & & 0.240 & \\
\hline Father Used UI in the Future & & 0.245 & 0.247 & 0.257 & 0.184 & & 0.179 & 0.195 & 0.190 & & 0.182 & \\
\hline P-value for test of equality & & 0.115 & 0.121 & 0.159 & 0.170 & & 0.163 & 0.456 & 0.617 & & 0.538 & \\
\hline \multicolumn{13}{|l|}{ Other Individual Controls } \\
\hline Age & $\checkmark$ & $\checkmark$ & $\checkmark$ & $\checkmark$ & $\checkmark$ & & $\checkmark$ & $\checkmark$ & $\checkmark$ & & $\checkmark$ & \\
\hline Marital Status & & & $\checkmark$ & $\checkmark$ & $\checkmark$ & & $\checkmark$ & $\checkmark$ & $\checkmark$ & & $\checkmark$ & \\
\hline UI Generosity Index & & & & $\checkmark$ & $\checkmark$ & & $\checkmark$ & $\checkmark$ & $\checkmark$ & & $\checkmark$ & \\
\hline Unemployment Rate & & & & & $\checkmark$ & & $\checkmark$ & $\checkmark$ & $\checkmark$ & & $\checkmark$ & \\
\hline Rural Residence & & & & & & & & & & & & \\
\hline Region of Residence & & & & & & & $\checkmark$ & $\checkmark$ & $\checkmark$ & & $\checkmark$ & \\
\hline \multicolumn{13}{|c|}{ Other Family Background Controls } \\
\hline Permanent Income & & & & & & & & $\checkmark$ & $\checkmark$ & & $\checkmark$ & \\
\hline Sources of Father's Income & & & & & & & & & $\checkmark$ & & $\checkmark$ & \\
\hline Rural Residence at age 15 & & & & & & & & & & & $\checkmark$ & \\
\hline Region of Residence at age 15 & & & & & & & & & & & $\checkmark$ & \\
\hline - log likelihood & 7844.4 & 7836.5 & 7834.6 & 7829.3 & 7675.4 & & 7662.6 & 7639.7 & 7612.4 & & 7587.4 & \\
\hline
\end{tabular}

Reported coefficients are from a logit model of the hazard rate to first UI use. and all have a p-value less than 0.001. Region of Residence refers to five different regions composed of different counties. Permanent Income refers to the average of total parental income over a 18 year period, while sources of the Father's income include indicator variables for whether the father reported income from farming, self-employment or asset income when the son was 15 to 16 years of age.

Number of observations is 35,488 representing 3,835 individuals.

Models (6) and (10) are not estimated because rural residence is not available in the Swedish data. 
Table $4 \mathrm{a}$

LOGIT ESTIMATES OF THE HAZARD RATE GOVERNING TIME TO FIRST USE OF UI: CANADA, MEN AGED 16 TO 30

Father Used UI in Past

Father Used UI in Future

Married

Provincial UI Generosity Index

Provincial Unemployment Rate

Rural Residence

Family Background

\begin{tabular}{lcccr} 
Parental Permanent Income & -0.344 & 0.059 & 0.000 & -0.0173 \\
Farming Income & -0.087 & 0.067 & 0.195 & -0.0044 \\
Fishing Income & 0.933 & 0.246 & 0.000 & 0.0470 \\
Self-Employment Income & 0.072 & 0.046 & 0.111 & 0.0036 \\
Asset Income & -0.204 & 0.037 & 0.000 & -0.0103 \\
Rural Residence at Age 15 & 0.105 & 0.059 & 0.078 & 0.0053 \\
& & & & \\
Region of Residence at Age 15 (Toronto Metropolitan as reference) & 0.161 & 0.000 & 0.0326 \\
Newfoundland & 0.648 & 0.106 & 0.003 & 0.0161 \\
Nova Scotia & 0.320 & 0.279 & 0.021 & 0.0324 \\
Prince Edward Island & 0.644 & 0.121 & 0.000 & 0.0230 \\
New Brunswick & 0.457 & 0.084 & 0.000 & 0.0241 \\
Quebec East & 0.478 & 0.088 & 0.000 & 0.0163 \\
Montreal Metropolitan & 0.324 & 0.085 & 0.000 & 0.0255 \\
Quebec West & 0.508 & 0.083 & 0.004 & 0.0122 \\
Eastern Ontario & 0.243 & 0.076 & 0.000 & 0.0140 \\
Central Ontario & 0.279 & 0.079 & 0.000 & 0.0224 \\
South-western Ontario & 0.445 & 0.105 & 0.000 & 0.0210 \\
Northern Ontario & 0.417 & 0.097 & 0.000 & 0.0191 \\
Manitoba & 0.379 & 0.010 & 0.000 & 0.0316 \\
Saskatchewan & 0.629 & 0.082 & 0.000 & 0.0267 \\
Alberta & 0.531 & 0.086 & 0.000 & 0.0262 \\
British Columbia & 0.521 & 0.939 & 0.427 & -0.0375 \\
Northwest Territories & -0.746 & 0.103 & 0.000 & 0.0732 \\
Yukon & 1.454 & & & \\
Constant & & & & \\
& -6.444 & & & \\
- log likelihood & $14,702.82$ & & & \\
Number of person-years & 57,208 & & & \\
\hline
\end{tabular}

\begin{tabular}{rrrr} 
Coefficient & $\begin{array}{r}\text { Robust } \\
\text { Standard Error }\end{array}$ & P-value & $\begin{array}{r}\text { Marginal } \\
\text { Effect }\end{array}$ \\
\hline 0.248 & 0.040 & 0.000 & 0.0125 \\
0.135 & 0.039 & 0.000 & 0.0068 \\
& & & \\
-0.248 & 0.062 & 0.000 & -0.0125 \\
0.274 & 0.193 & 0.156 & 0.0138 \\
0.035 & 0.013 & 0.009 & 0.0018 \\
0.231 & 0.061 & 0.000 & 0.0116
\end{tabular}

Other controls include a series of indicator variables for each age from 17 to 30 years. The number of observations is 57,208 representing 6,308 individuals. Standard errors are robust to heteroscedasticity and correct for the clustering of observations by individuals. Marginal effects are calculated as $\mathcal{L}\left(\boldsymbol{\beta}^{\prime} \mathbf{x}\right)\left[1-\mathcal{L}\left(\boldsymbol{\beta}^{\prime} \mathbf{x}\right)\right] \boldsymbol{\beta}$ where $\mathcal{L}()$ represents the logistic probability distribution, $\boldsymbol{\beta}$ the vector of estimated coefficients, and $\mathbf{x}$ the sample averages of the co-variates (indicator variables also being set at their sample proportions). As such these marginal effects are approximations of the impact of the binary co-variates in the model. 
Table 4b

LOGIT ESTIMATES OF THE HAZARD RATE GOVERNING TIME TO FIRST USE OF UI: SWEDEN, MEN AGED 16 TO 28

\begin{tabular}{|c|c|c|c|c|}
\hline & Coefficient & $\begin{array}{r}\text { Robust } \\
\text { Standard Error } \\
\end{array}$ & P-value & $\begin{array}{r}\text { Marginal } \\
\text { Effect } \\
\end{array}$ \\
\hline Father Used UI in Past & 0.244 & 0.063 & 0.000 & 0.0088 \\
\hline Father Used UI in Future & 0.182 & 0.063 & 0.004 & 0.0066 \\
\hline Married & 0.075 & 0.118 & 0.528 & 0.0027 \\
\hline UI Generosity Index & -0.351 & 0.137 & 0.010 & -0.0127 \\
\hline Unemployment Rate & 0.113 & 0.012 & 0.000 & 0.0041 \\
\hline \multicolumn{5}{|l|}{ Family Background } \\
\hline Parental Permanent Income & -0.191 & 0.027 & 0.000 & -0.0069 \\
\hline Farming Income & -0.268 & 0.098 & 0.006 & -0.0097 \\
\hline Self-Employment Income & 0.007 & 0.069 & 0.914 & 0.0002 \\
\hline Positive Asset Income & -0.248 & 0.094 & 0.008 & -0.0089 \\
\hline Negative Asset Income & 0.067 & 0.084 & 0.421 & 0.0024 \\
\hline \multicolumn{5}{|c|}{ Region of Residence (Stockholm county as reference case) } \\
\hline Göteborg & 0.668 & 0.219 & 0.002 & 0.0241 \\
\hline Malmö & 0.432 & 0.259 & 0.096 & 0.0156 \\
\hline Forest counties & 0.512 & 0.229 & 0.025 & 0.0185 \\
\hline Other counties & 0.342 & 0.162 & 0.035 & 0.0123 \\
\hline \multicolumn{5}{|c|}{ Region of Residence at Age 15 (Stockholm county as reference case) } \\
\hline Göteborg & -0.646 & 0.228 & 0.005 & -0.0233 \\
\hline Malmö & -0.143 & 0.261 & 0.582 & -0.0052 \\
\hline Forest counties & -0.017 & 0.215 & 0.937 & -0.0006 \\
\hline Other counties & -0.068 & 0.157 & 0.666 & -0.0024 \\
\hline Constant & -7.623 & 0.461 & 0.000 & \\
\hline - log likelihood & \multicolumn{2}{|c|}{$7,587.36$} & & \\
\hline Number of person-years & \multicolumn{2}{|c|}{35,488} & & \\
\hline
\end{tabular}

Other controls include a series of indicator variables for each age from 17 to 28 years. The number of observations is 35,488 representing 3,835 individuals. Standard errors are robust to heteroscedasticity and correct for the clustering of observations by individuals. Marginal effects are calculated as described in the note to Table 4a. 
Table 5a

ESTIMATED HAZARD AND SURVIVOR RATES:

TIME TO FIRST UI SPELL, CANADA

\begin{tabular}{|c|c|c|c|c|c|c|}
\hline \multirow[b]{2}{*}{ Age } & \multicolumn{3}{|c|}{ Hazard Rates } & \multicolumn{3}{|c|}{ Survivor Rates } \\
\hline & $\begin{array}{c}\text { Father Did } \\
\text { Not Use } \\
\text { UI }\end{array}$ & $\begin{array}{c}\text { Father } \\
\text { Used UI in } \\
\text { Future }\end{array}$ & $\begin{array}{c}\text { Father } \\
\text { Used UI in } \\
\text { Past }\end{array}$ & $\begin{array}{c}\text { Father Did } \\
\text { Not Use } \\
\text { UI }\end{array}$ & $\begin{array}{c}\text { Father } \\
\text { Used UI in } \\
\text { Future }\end{array}$ & $\begin{array}{c}\text { Father } \\
\text { Used UI in } \\
\text { Past }\end{array}$ \\
\hline 16 & 0.0041 & 0.0047 & 0.0052 & 0.9959 & 0.9953 & 0.9948 \\
\hline 17 & 0.0152 & 0.0174 & 0.0194 & 0.9807 & 0.9780 & 0.9754 \\
\hline 18 & 0.0452 & 0.0514 & 0.0572 & 0.9364 & 0.9277 & 0.9196 \\
\hline 19 & 0.1154 & 0.1299 & 0.1432 & 0.8283 & 0.8072 & 0.7879 \\
\hline 20 & 0.1320 & 0.1483 & 0.1631 & 0.7189 & 0.6875 & 0.6594 \\
\hline 21 & 0.1250 & 0.1405 & 0.1546 & 0.6291 & 0.5909 & 0.5575 \\
\hline 22 & 0.1168 & 0.1314 & 0.1448 & 0.5556 & 0.5132 & 0.4767 \\
\hline 23 & 0.0914 & 0.1033 & 0.1142 & 0.5048 & 0.4602 & 0.4223 \\
\hline 24 & 0.0784 & 0.0887 & 0.0983 & 0.4652 & 0.4194 & 0.3808 \\
\hline 25 & 0.0737 & 0.0834 & 0.0925 & 0.4310 & 0.3844 & 0.3456 \\
\hline 26 & 0.0776 & 0.0878 & 0.0973 & 0.3975 & 0.3506 & 0.3119 \\
\hline 27 & 0.0705 & 0.0799 & 0.0886 & 0.3695 & 0.3226 & 0.2843 \\
\hline 28 & 0.0568 & 0.0644 & 0.0716 & 0.3485 & 0.3018 & 0.2640 \\
\hline 29 & 0.0421 & 0.0479 & 0.0533 & 0.3339 & 0.2874 & 0.2499 \\
\hline 30 & 0.0299 & 0.0340 & 0.0379 & 0.3239 & 0.2776 & 0.2404 \\
\hline
\end{tabular}

Note: Hazard Rates are calculated for Model (12) of Table 3a at the point of age-specific sample means for the remaining co-variates 
Table 5b

ESTIMATED HAZARD AND SURVIVOR RATES:

TIME TO FIRST UI SPELL, SWEDEN

\begin{tabular}{|c|c|c|c|c|c|c|}
\hline \multirow[b]{2}{*}{ Age } & \multicolumn{3}{|c|}{ Hazard Rates } & \multicolumn{3}{|c|}{ Survivor Rates } \\
\hline & $\begin{array}{c}\text { Father Did } \\
\text { Not Use } \\
\text { UI }\end{array}$ & $\begin{array}{c}\text { Father } \\
\text { Used UI in } \\
\text { Future }\end{array}$ & $\begin{array}{c}\text { Father } \\
\text { Used UI in } \\
\text { Past }\end{array}$ & $\begin{array}{c}\text { Father Did } \\
\text { Not Use } \\
\text { UI }\end{array}$ & $\begin{array}{c}\text { Father } \\
\text { Used UI in } \\
\text { Future }\end{array}$ & $\begin{array}{c}\text { Father } \\
\text { Used UI in } \\
\text { Past }\end{array}$ \\
\hline 16 & 0.0011 & 0.0013 & 0.0014 & 0.9989 & 0.9987 & 0.9986 \\
\hline 17 & 0.0119 & 0.0142 & 0.0151 & 0.9870 & 0.9845 & 0.9835 \\
\hline 18 & 0.0670 & 0.0793 & 0.0839 & 0.9209 & 0.9064 & 0.9010 \\
\hline 19 & 0.0635 & 0.0752 & 0.0796 & 0.8624 & 0.8383 & 0.8293 \\
\hline 20 & 0.0896 & 0.1056 & 0.1116 & 0.7851 & 0.7498 & 0.7367 \\
\hline 21 & 0.0916 & 0.1086 & 0.1139 & 0.7132 & 0.6683 & 0.6528 \\
\hline 22 & 0.0578 & 0.0685 & 0.0726 & 0.6720 & 0.6225 & 0.6054 \\
\hline 23 & 0.0615 & 0.0729 & 0.0772 & 0.6306 & 0.5772 & 0.5587 \\
\hline 24 & 0.0497 & 0.0590 & 0.0625 & 0.5993 & 0.5431 & 0.5238 \\
\hline 25 & 0.0533 & 0.0633 & 0.0670 & 0.5674 & 0.5087 & 0.4887 \\
\hline 26 & 0.0667 & 0.0790 & 0.0836 & 0.5295 & 0.4685 & 0.4478 \\
\hline 27 & 0.0617 & 0.0732 & 0.0774 & 0.4968 & 0.4343 & 0.4132 \\
\hline 28 & 0.0547 & 0.0649 & 0.0687 & 0.4697 & 0.4061 & 0.3848 \\
\hline
\end{tabular}

Note: Hazard Rates are calculated for Model (11) of Table $3 \mathrm{~b}$ at the point of age-specific sample means for the remaining co-variates 
Table $6 \mathrm{a}$

THE IMPACT OF INDIVIDUAL LEARNING AND SOCIAL CAPITAL ON THE PROBABILITY OF USING UI: SUMMARY OF ESTIMATES FROM RANDOM EFFECTS PROBIT MODELS FOR CANADIAN MEN

\begin{tabular}{|c|c|c|c|c|c|c|c|c|c|c|c|c|c|}
\hline & (1) & (2) & (3) & (4) & (5) & (6) & (7) & (8) & (9) & (10) & (11) & (12) & (13) \\
\hline Individual Used UI in the Past & 0.310 & 0.277 & 0.331 & 0.113 & 0.116 & 0.149 & 0.148 & 0.162 & 0.164 & 0.148 & 0.146 & 0.140 & 0.134 \\
\hline Father Used UI in the Past & & 0.200 & 0.294 & 0.269 & 0.270 & 0.238 & 0.238 & 0.229 & 0.230 & 0.197 & 0.195 & 0.193 & 0.193 \\
\hline Individual and Father Used UI & & & -0.159 & -0.103 & -0.102 & -0.096 & -0.095 & -0.093 & -0.094 & -0.083 & -0.086 & -0.087 & -0.089 \\
\hline \multicolumn{14}{|l|}{ Individual Characteristics } \\
\hline Age and Age Squared & & & & $\checkmark$ & $\checkmark$ & $\checkmark$ & $\checkmark$ & $\checkmark$ & $\checkmark$ & $\checkmark$ & $\checkmark$ & $\checkmark$ & $\checkmark$ \\
\hline Marital Status & & & & & $\checkmark$ & $\checkmark$ & $\checkmark$ & $\checkmark$ & $\checkmark$ & $\checkmark$ & $\checkmark$ & $\checkmark$ & $\checkmark$ \\
\hline Provincial Unemployment Rate & & & & & & $\checkmark$ & $\checkmark$ & $\checkmark$ & $\checkmark$ & $\checkmark$ & $\checkmark$ & $\checkmark$ & $\checkmark$ \\
\hline Provincial UI Generosity & & & & & & & $\checkmark$ & $\checkmark$ & $\checkmark$ & $\checkmark$ & $\checkmark$ & $\checkmark$ & $\checkmark$ \\
\hline Rural Residence & & & & & & & & $\checkmark$ & $\checkmark$ & $\checkmark$ & $\checkmark$ & $\checkmark$ & $\checkmark$ \\
\hline Region of Residence & & & & & & & & & $\checkmark$ & $\checkmark$ & $\checkmark$ & $\checkmark$ & $\checkmark$ \\
\hline \multicolumn{14}{|l|}{ Family Background } \\
\hline Parental Permanent Income & & & & & & & & & & $\checkmark$ & $\checkmark$ & $d$ & $d$ \\
\hline Sources of Father's Income & & & & & & & & & & & $\checkmark$ & $\checkmark$ & $\checkmark$ \\
\hline Rural Resident at age 15 & & & & & & & & & & & & $\checkmark$ & $\checkmark$ \\
\hline Region of Residence at age 15 & & & & & & & & & & & & & $\checkmark$ \\
\hline - log likelihood & $39,267.3$ & $39,153.6$ & $39,130.4$ & $38,218.7$ & $38,185.8$ & $37,765.0$ & $37,762.0$ & $37,668.4$ & $37,599.5$ & $37,516.3$ & $37,450.2$ & $37,428.3$ & $37,414.2$ \\
\hline
\end{tabular}

The dependent variable is a $0-1$ indicator of whether the individual received income from UI in a particular year. The reported coefficients are from a random effects probit model in which the unobserved individual heterogeneity is assumed to be normally distributed. All reported coefficients have a p-value of less than 0.000 .

Number of observations is 100,795 representing annual observations on 6,308 individuals from the ages of 16 to 31 .

All models include a lagged value of the dependent variable. Region of Residence refers to 16 provincial and sub-provincial regions defined according to the first digit of the postal code. Rural Residence is defined on the basis of the second digit of the postal code. Parental Permanent Income refers to the average of total parental income over a twenty year period, while sources of the Father's income includes four indicator variables for whether the father reported income from farming, fishing, self-employment, or assets when the
son was 15 to 16 years of age. 
Table $6 \mathrm{~b}$

THE IMPACT OF INDIVIDUAL LEARNING AND SOCIAL CAPITAL ON THE PROBABILITY OF USING UI: SUMMARY OF ESTIMATES FROM RANDOM EFFECTS PROBIT MODELS FOR SWEDISH MEN

\begin{tabular}{|c|c|c|c|c|c|c|c|c|c|c|c|c|c|}
\hline & (1) & (2) & (3) & (4) & (5) & (6) & (7) & (8) & (9) & (10) & (11) & (12) & (13) \\
\hline Individual Used UI in the Past & 0.441 & 0.420 & 0.437 & 0.297 & 0.299 & 0.317 & 0.296 & & 0.290 & 0.275 & 0.261 & & 0.264 \\
\hline Father Used UI in the Past & & 0.217 & 0.260 & 0.231 & 0.230 & 0.179 & 0.175 & & 0.180 & 0.156 & 0.144 & & 0.145 \\
\hline Individual and Father Used UI & & & $-0.085^{\text {n.s }}$ & $-0.057^{\text {n.s }}$ & $-0.057^{\text {n.s }}$ & $-0.050^{\text {n.s }}$ & $-0.051^{\text {n.s }}$ & & $-0.052^{\text {n.s }}$ & $-0.043^{\text {n.s }}$ & $-0.035^{\text {n.s }}$ & & $-0.041^{\text {n.s }}$ \\
\hline \multicolumn{14}{|l|}{ Individual Characteristics } \\
\hline Age and Age Squared & & & & $\checkmark$ & $\checkmark$ & $\checkmark$ & $\checkmark$ & & $\checkmark$ & $\checkmark$ & $\checkmark$ & & $\checkmark$ \\
\hline Marital Status & & & & & $\checkmark$ & $\checkmark$ & $\checkmark$ & & $\checkmark$ & $\checkmark$ & $\checkmark$ & & $\checkmark$ \\
\hline Provincial Unemployment Rate & & & & & & $\checkmark$ & $\checkmark$ & & $\checkmark$ & $\checkmark$ & $\checkmark$ & & $\checkmark$ \\
\hline Provincial UI Generosity & & & & & & & $\checkmark$ & & $\checkmark$ & $\checkmark$ & $\checkmark$ & & $\checkmark$ \\
\hline Rural Residence & & & & & & & & & & & & & \\
\hline Region of Residence & & & & & & & & & $\checkmark$ & $\checkmark$ & $\checkmark$ & & $\checkmark$ \\
\hline \multicolumn{14}{|l|}{ Family Background } \\
\hline Parental Permanent Income & & & & & & & & & & $\checkmark$ & $\checkmark$ & & $\checkmark$ \\
\hline Sources of Father's Income & & & & & & & & & & & $\checkmark$ & & $\checkmark$ \\
\hline Rural Resident at age 15 & & & & & & & & & & & & & \\
\hline Region of Residence at age 15 & & & & & & & & & & & & & $\checkmark$ \\
\hline - log likelihood & $15,235.8$ & $15,179.9$ & $15,177.7$ & $15,027.7$ & $14,784.6$ & $15,021.9$ & $14,614.3$ & & $14,593.0$ & $14,564.9$ & $14,533.4$ & & $14,487.4$ \\
\hline
\end{tabular}

The dependent variable is a $0-1$ indicator of whether the individual received income from UI in a particular year. The reported coefficients are from a random effects probit model in which the unobserved individual heterogeneity is assumed to be normally distributed. All reported coefficients have a p-value of less than 0.000 except those indicated with ${ }^{\text {n.s }}$.

Number of observations is 49,133 representing annual observations on 3,835 individuals from the ages of 16 to 28

All models include a lagged value of the dependent variable. Region of Residence refers to five different regions composed of different counties. Permanent Income refers to the average of total parental income over a 18 year period, while sources of the Father's income include indicator variables for whether the father reported income from farming. self-employment or asset income when the son was 15 to 16 years of age.

Models (8) and (12) are not estimated as there is no information on rural residence in the Swedish data. 
Table $7 \mathrm{a}$

RANDOM EFFECT PROBIT ESTIMATES OF THE PROBABILITY OF UI USE: CANADIAN MEN FROM THE AGES OF 16 TO 31

\begin{tabular}{|c|c|c|c|c|}
\hline & Coefficient & $\begin{array}{l}\text { Robust } \\
\text { d Error }\end{array}$ & P-value & $\begin{array}{r}\text { Marginal } \\
\text { Effect }\end{array}$ \\
\hline Individual Used UI in Past & 0.134 & 0.022 & 0.000 & 0.0193 \\
\hline Father Used UI in Past & 0.193 & 0.021 & 0.000 & 0.0278 \\
\hline $\begin{array}{l}\text { Individual and Father Used UI } \\
\text { in Past }\end{array}$ & -0.089 & 0.025 & 0.000 & -0.0127 \\
\hline Lagged Dependent Variable & 1.196 & 0.015 & 0.000 & 0.1720 \\
\hline Age (in decades) & 7.522 & 0.212 & 0.000 & \\
\hline Age Squared & -1.528 & 0.046 & 0.000 & \\
\hline Married & -0.133 & 0.016 & 0.000 & -0.0191 \\
\hline Provincial UI Generosity Index & 0.030 & 0.060 & 0.612 & 0.0044 \\
\hline Provincial Unemployment Rate & 0.066 & 0.004 & 0.000 & 0.0095 \\
\hline Rural Residence & 0.096 & 0.019 & 0.000 & 0.0138 \\
\hline \multicolumn{5}{|c|}{ Region of Residence (Toronto Metropolitan as reference case) } \\
\hline Newfoundland & -0.290 & 0.090 & 0.001 & -0.0417 \\
\hline Nova Scotia & -0.068 & 0.072 & 0.345 & -0.0098 \\
\hline Prince Edward Island & 0.049 & 0.179 & 0.786 & 0.0070 \\
\hline New Brunswick & 0.023 & 0.084 & 0.782 & 0.0034 \\
\hline Quebec East & 0.110 & 0.078 & 0.157 & 0.0159 \\
\hline Montreal Metropolitan & -0.026 & 0.067 & 0.700 & -0.0037 \\
\hline Quebec West & -0.017 & 0.067 & 0.796 & -0.0025 \\
\hline Eastern Ontario & 0.036 & 0.054 & 0.509 & 0.0051 \\
\hline Central Ontario & 0.021 & 0.039 & 0.591 & 0.0030 \\
\hline South-western Ontario & 0.141 & 0.053 & 0.008 & 0.0202 \\
\hline Northern Ontario & 0.117 & 0.070 & 0.095 & 0.0169 \\
\hline Manitoba & 0.087 & 0.079 & 0.270 & 0.0125 \\
\hline Saskatchewan & 0.305 & 0.076 & 0.000 & 0.0438 \\
\hline Alberta & 0.074 & 0.056 & 0.187 & 0.0106 \\
\hline British Columbia & 0.104 & 0.055 & 0.060 & 0.0149 \\
\hline \multicolumn{5}{|l|}{ Family Background } \\
\hline Parental Permanent Income & -0.133 & 0.015 & 0.000 & -0.0192 \\
\hline Farming Income & -0.011 & 0.030 & 0.712 & -0.0016 \\
\hline Fishing Income & 0.632 & 0.080 & 0.000 & 0.0909 \\
\hline Self-Employment Income & 0.026 & 0.021 & 0.227 & 0.0037 \\
\hline Asset Income & -0.117 & 0.016 & 0.000 & -0.0168 \\
\hline Rural Residence at Age 15 & 0.121 & 0.022 & 0.000 & 0.0175 \\
\hline
\end{tabular}


Table 7a (concluded)

RAMDOM EFFECT PROBIT ESTIMATES OF THE PROBABILITY OF UI USE: CANADIAN MEN FROM THE AGES OF 16 TO 31

\begin{tabular}{|c|c|c|c|c|}
\hline & Coefficient & $\begin{array}{r}\text { Robust } \\
\text { Standard Error } \\
\end{array}$ & P-value & $\begin{array}{r}\text { Marginal } \\
\text { Effect }\end{array}$ \\
\hline \multicolumn{5}{|c|}{ Region of Residence at Age 15 (Toronto Metropolitan as reference case) } \\
\hline Newfoundland & 0.288 & 0.082 & 0.000 & 0.0414 \\
\hline Nova Scotia & 0.129 & 0.075 & 0.084 & 0.0186 \\
\hline Prince Edward Island & 0.196 & 0.174 & 0.259 & 0.0282 \\
\hline New Brunswick & 0.187 & 0.085 & 0.028 & 0.0269 \\
\hline Quebec East & 0.165 & 0.080 & 0.039 & 0.0238 \\
\hline Montreal Metropolitan & 0.090 & 0.069 & 0.194 & 0.0129 \\
\hline Quebec West & 0.182 & 0.070 & 0.009 & 0.0261 \\
\hline Eastern Ontario & 0.074 & 0.059 & 0.209 & 0.0106 \\
\hline Central Ontario & 0.114 & 0.045 & 0.011 & 0.0163 \\
\hline South-western Ontario & 0.010 & 0.057 & 0.081 & 0.0143 \\
\hline Northern Ontario & 0.139 & 0.073 & 0.055 & 0.0201 \\
\hline Manitoba & 0.074 & 0.080 & 0.352 & 0.0107 \\
\hline Saskatchewan & 0.102 & 0.078 & 0.190 & 0.0147 \\
\hline Alberta & 0.161 & 0.061 & 0.009 & 0.0232 \\
\hline British Columbia & 0.071 & 0.061 & 0.242 & 0.0102 \\
\hline Northwest Territories & -0.754 & 0.492 & 0.126 & -0.1083 \\
\hline Yukon & 0.317 & 0.545 & 0.561 & 0.0456 \\
\hline Constant & -11.1 & 0.238 & 0.000 & \\
\hline $\ln \sigma_{v}$ & -1.89 & 0.061 & 0.000 & \\
\hline$\sigma_{v}$ & 0.389 & 0.012 & & \\
\hline$\rho$ & 0.132 & 0.0069 & & \\
\hline - log likelihood & 37,4 & 4.2 & & \\
\hline
\end{tabular}

The number of observations is 100,795 representing annual observations on 6,308 individuals from the ages of 16 to 31 .

The dependent variable is a 0-1 indicator of whether the individual received income from UI in a particular year. The reported coefficients are from a random effects probit model in which the unobserved individual heterogeneity is assumed to be normally distributed, with standard deviation $\sigma_{y}$. The proportion of the total variance contributed by the individual level variance is $\rho=\sigma_{v} /\left(1+\sigma_{v}\right)$. A likelihood ratio test of the null hypothesis that $\rho=0$ yields a $\chi^{2}(1)$ statistics of 610.5 with an associated p-value of less than 0.0001 . Marginal effects are calculated as $\varphi\left(\boldsymbol{\beta}^{\prime} \mathbf{x}\right) \boldsymbol{\beta}$. where $\varphi()$ represents the normal probability density function, $\boldsymbol{\beta}$ the vector of estimated coefficients, and $\mathbf{x}$ the sample averages fo the co-variates (indicator variables also begin set at their sample proportions). As such these marginal effects are approximations of the impact of the binary co-variates in the model. co-variates (indicator variables also begin set at their sample proportions). As such these
The overall estimated probability of receiving UI (at the point of sample means) is 0.1438 . 
Table $7 b$

RANDOM EFFECT PROBIT ESTIMATES OF THE PROBABILITY OF UI USE: SWEDISH MEN FROM THE AGES OF 16 TO 28

\begin{tabular}{|c|c|c|c|c|}
\hline & Coefficient & $\begin{array}{r}\text { Robust } \\
\text { Standard Error } \\
\end{array}$ & P-value & $\begin{array}{r}\text { Marginal } \\
\text { Effect }\end{array}$ \\
\hline Individual Used UI in Past & 0.264 & 0.026 & 0.000 & 0.0464 \\
\hline Father Used UI in Past & 0.145 & 0.030 & 0.000 & 0.0254 \\
\hline $\begin{array}{l}\text { Individual and Father Used UI } \\
\text { in Past }\end{array}$ & -0.041 & 0.041 & 0.325 & -0.0072 \\
\hline Lagged Dependent Variable & 1.440 & 0.026 & 0.000 & 0.2532 \\
\hline Age (in decades) & 6.764 & 0.372 & 0.000 & \\
\hline Age Squared & -1.501 & 0.084 & 0.000 & \\
\hline Married & 0.029 & 0.035 & 0.406 & 0.0051 \\
\hline UI Generosity Index & -0.147 & 0.000 & 0.000 & -0.0258 \\
\hline Unemployment Rate & 0.078 & 0.004 & 0.000 & 0.0136 \\
\hline \multicolumn{5}{|l|}{ Family Background } \\
\hline Parental Permanent Income & -0.080 & 0.010 & 0.000 & -0.0140 \\
\hline Farming Income & -0.128 & 0.034 & 0.000 & -0.0225 \\
\hline Self-Employment Income & -0.032 & 0.026 & 0.206 & -0.0057 \\
\hline Positive Asset Income & -0.092 & 0.033 & 0.005 & -0.0162 \\
\hline Negative Asset Income & 0.024 & 0.029 & 0.407 & 0.0042 \\
\hline \multicolumn{5}{|c|}{ Region of Residence (Stockholm county as reference case) } \\
\hline Göteborg & 0.102 & 0.079 & 0.197 & 0.0180 \\
\hline Malmö & 0.136 & 0.082 & 0.099 & 0.0239 \\
\hline Forest counties & 0.170 & 0.068 & 0.013 & 0.0298 \\
\hline Other counties & 0.108 & 0.056 & 0.055 & 0.0191 \\
\hline \multicolumn{5}{|c|}{ Region of Residence (Stockholm county as reference case) } \\
\hline Göteborg & -0.141 & 0.082 & 0.086 & -0.0247 \\
\hline Malmö & -0.082 & 0.084 & 0.327 & -0.0144 \\
\hline Forest counties & -0.116 & 0.064 & 0.068 & -0.0204 \\
\hline Other counties & -0.090 & 0.055 & 0.104 & -0.0159 \\
\hline Constant & -9.510 & 0.410 & 0.000 & \\
\hline $\ln \sigma_{v}$ & -1.451 & 0.106 & 0.000 & \\
\hline$\sigma_{v}$ & 0.438 & 0.023 & & \\
\hline$\rho$ & 1.61 & 0.014 & & \\
\hline - log likelihood & \multicolumn{2}{|c|}{$14,487.4$} & & \\
\hline
\end{tabular}

The number of observations is 48,920 representing annual observations on 3,818 individuals from the ages of 16 to 28 .

The dependent variable is a $0-1$ indicator of whether the individual received income from UI in a particular year. The reported coefficients are from a random effects probit model in which the unobserved individual heterogeneity is assumed to be normally distributed. with standard deviation $\sigma_{v}$. The proportion of the total variance contributed by the individual level variance is $\rho=\sigma_{\sqrt{ }} /\left(1+\sigma_{v}\right)$. A likelihood ratio test of the null hypothesis that $\rho=0$ yields a yields a $\chi^{2}(1)$ statistics of 197.5 with an associated p-value of less than 0.0001. Marginal effects are calculated as $\varphi\left(\boldsymbol{\beta}^{\prime} \mathbf{x}\right) \boldsymbol{\beta}$, where $\varphi()$ represents the normal probability density function, $\boldsymbol{\beta}$ the vector of estimated coefficients, and $\mathbf{x}$ the sample averages fo the co-variates (indicator variables also begin set at their sample proportions). As such these marginal effects are approximations of the impact of the binary co-variates in the model. The overall estimated probability of receiving UI (at the point of sample means) is 0.1002 . 
Figure 1

SCHEMATIC OVERVIEW OF THE INTERGENERATIONAL TRANSMISSION OF UI STATUS

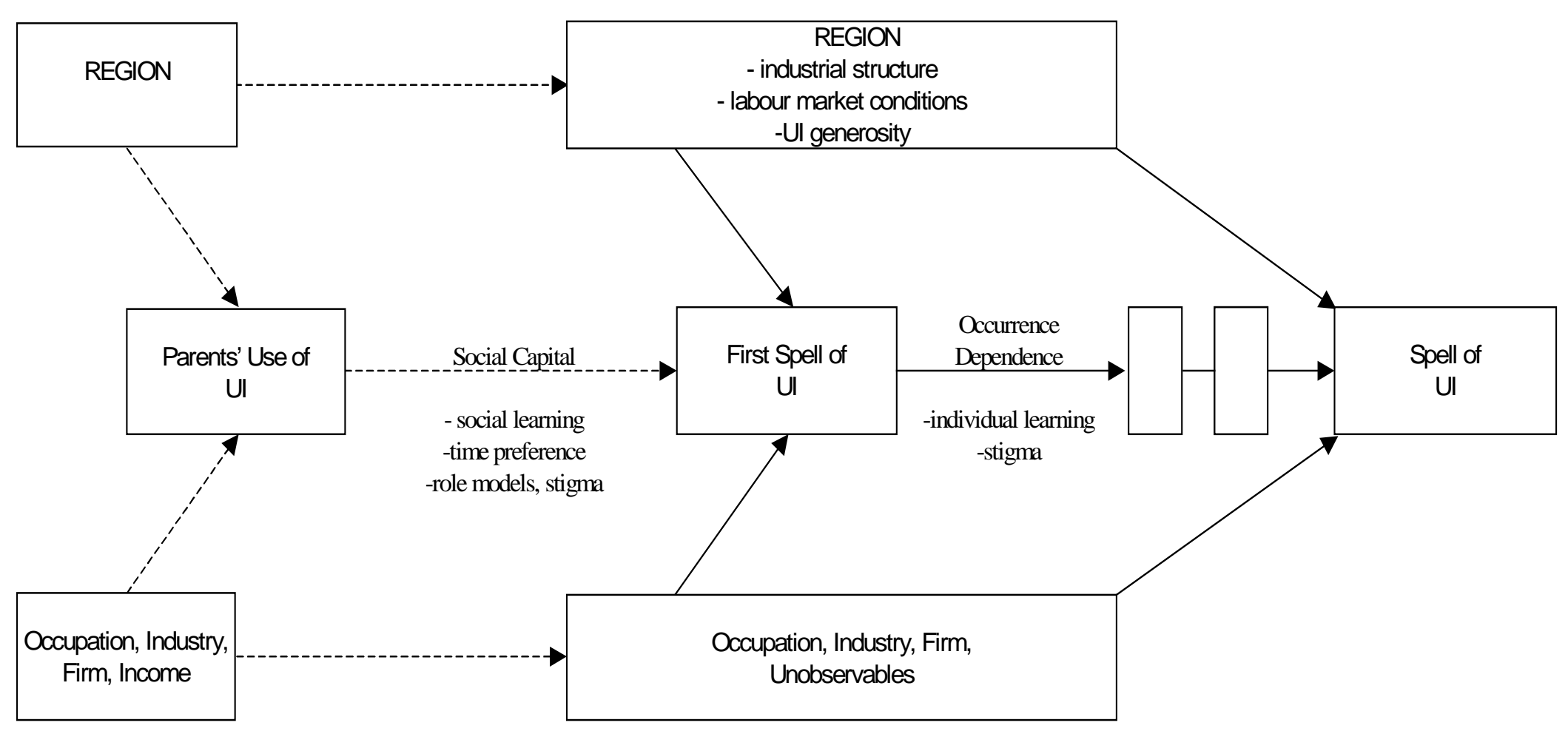


Figure 2a

Estimated Hazard Rates Governing Time to First UI Use:

Canadian Men between 16 and 30 Years

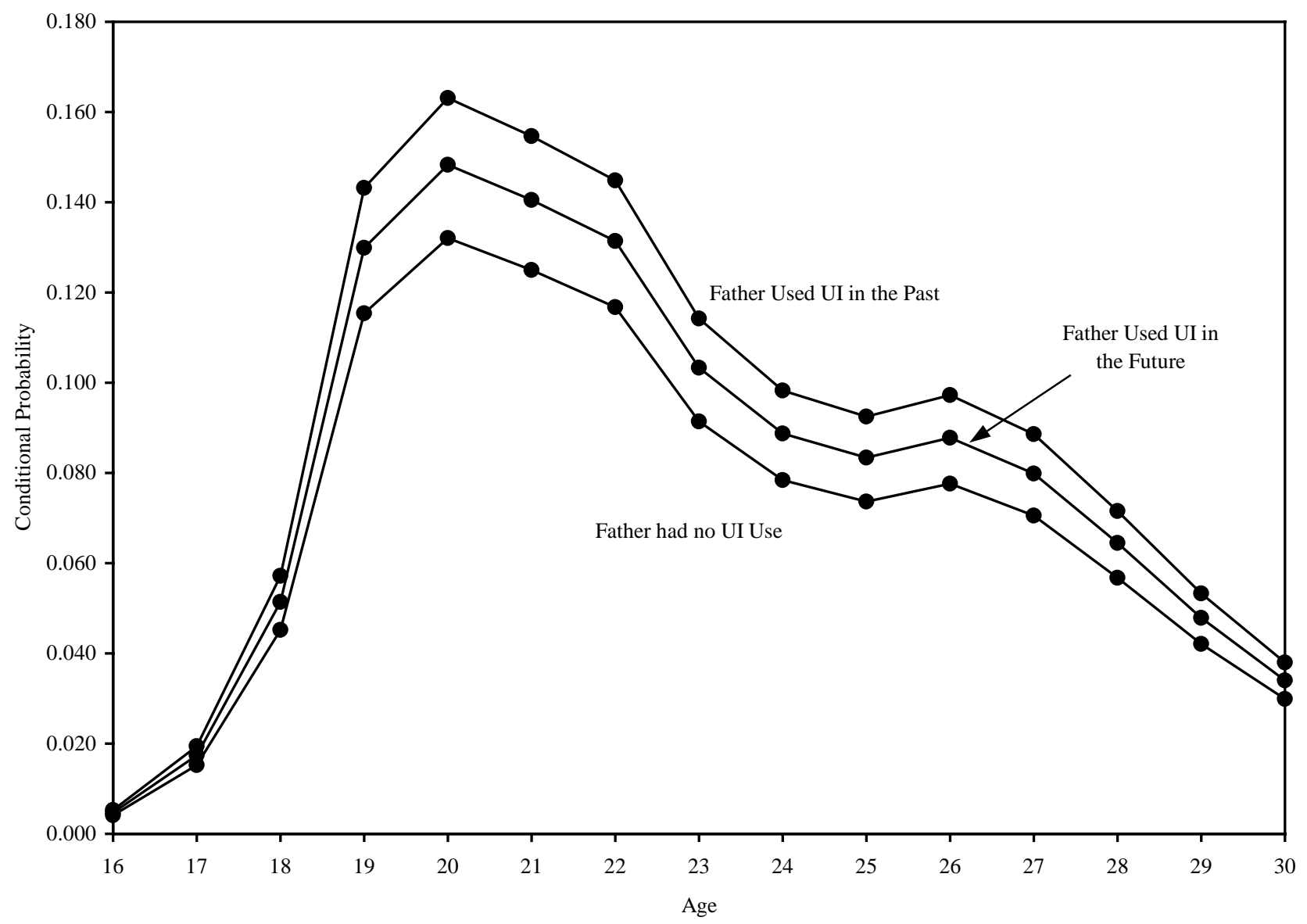


Figure 2b

Estimated Hazard Rates Governing Time to First UI Use:

Swedish Men between 16 and 28 Years

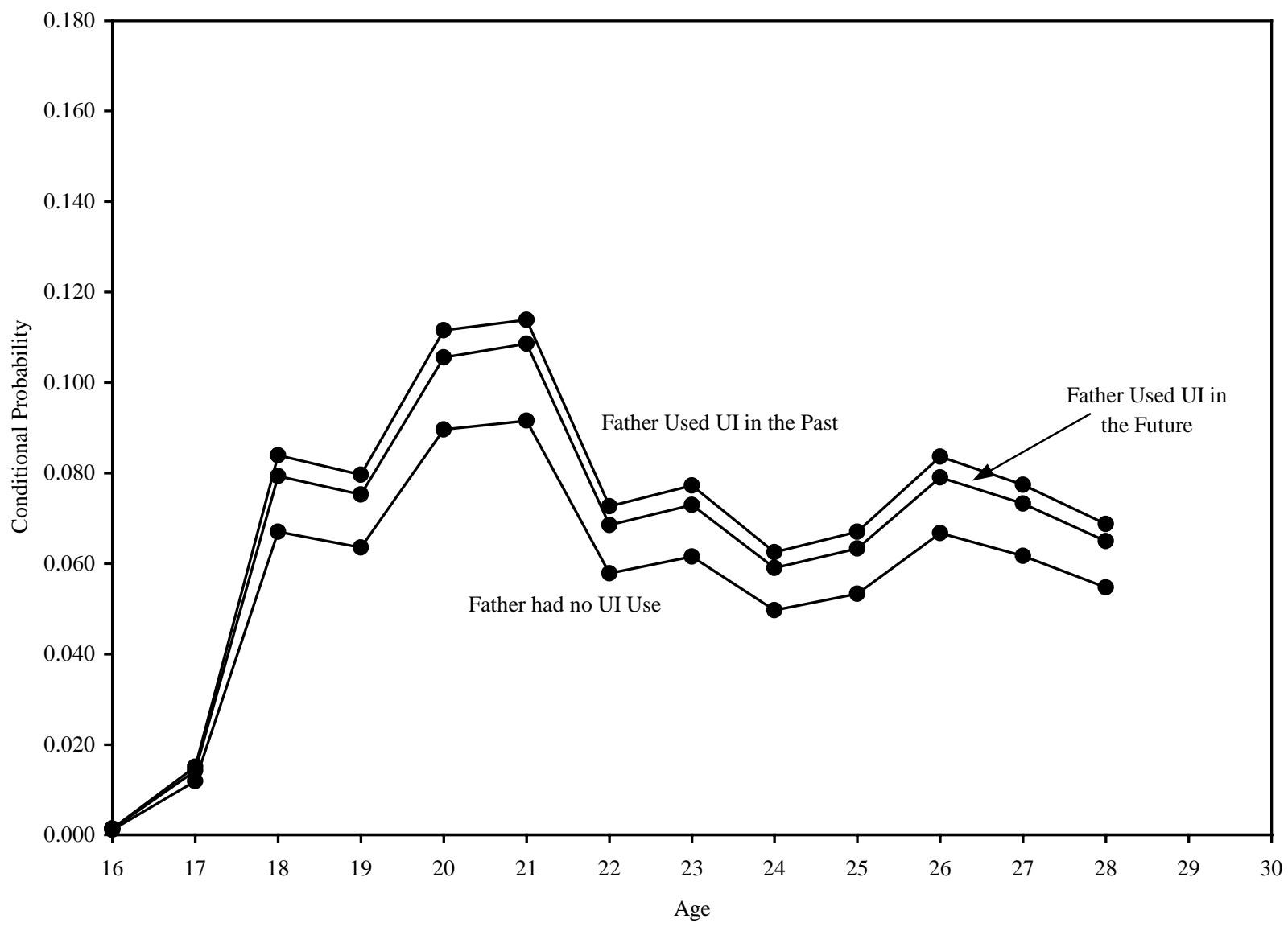




\section{IZA Discussion Papers}

\begin{tabular}{|c|c|c|c|c|}
\hline No. & Author(s) & Title & Area & Date \\
\hline 91 & M. Lechner & $\begin{array}{l}\text { Identification and Estimation of Causal Effects of } \\
\text { Multiple Treatments Under the Conditional } \\
\text { Independence Assumption }\end{array}$ & 6 & $12 / 99$ \\
\hline 92 & R. E. Wright & The Rate of Return to Private Schooling & 5 & $12 / 99$ \\
\hline 93 & M. Lechner & $\begin{array}{l}\text { An Evaluation of Public-Sector-Sponsored } \\
\text { Continuous Vocational Training Programs in East } \\
\text { Germany }\end{array}$ & 6 & $12 / 99$ \\
\hline 94 & $\begin{array}{l}\text { M. Eichler } \\
\text { M. Lechner }\end{array}$ & $\begin{array}{l}\text { An Evaluation of Public Employment Programmes } \\
\text { in the East German State of Sachsen-Anhalt }\end{array}$ & 6 & $12 / 99$ \\
\hline 95 & $\begin{array}{l}\text { P. Cahuc } \\
\text { A. Zylberberg }\end{array}$ & Job Protection, Minimum Wage and Unemployment & 3 & $12 / 99$ \\
\hline 96 & $\begin{array}{l}\text { P. Cahuc } \\
\text { A. Zylberberg }\end{array}$ & $\begin{array}{l}\text { Redundancy Payments, Incomplete Labor } \\
\text { Contracts, Unemployment and Welfare }\end{array}$ & 3 & $12 / 99$ \\
\hline 97 & A. Barrett & $\begin{array}{l}\text { Irish Migration: Characteristics, Causes and } \\
\text { Consequences }\end{array}$ & 1 & $12 / 99$ \\
\hline 98 & $\begin{array}{l}\text { J.P. Haisken-DeNew } \\
\text { C. M. Schmidt }\end{array}$ & $\begin{array}{l}\text { Industry Wage Differentials Revisited: A } \\
\text { Longitudinal Comparison of Germany and USA }\end{array}$ & $1 / 5$ & $12 / 99$ \\
\hline 99 & R. T. Riphahn & $\begin{array}{l}\text { Residential Location and Youth Unemployment: } \\
\text { The Economic Geography of School-to-Work- } \\
\text { Transitions }\end{array}$ & 1 & $12 / 99$ \\
\hline 100 & $\begin{array}{l}\text { J. Hansen } \\
\text { M. Lofstrom }\end{array}$ & $\begin{array}{l}\text { Immigrant Assimilation and Welfare Participation: } \\
\text { Do Immigrants Assimilate Into or Out-of Welfare? }\end{array}$ & $1 / 3$ & $12 / 99$ \\
\hline 101 & $\begin{array}{l}\text { L. Husted } \\
\text { H. S. Nielsen } \\
\text { M. Rosholm } \\
\text { N. Smith }\end{array}$ & $\begin{array}{l}\text { Employment and Wage Assimilation of Male First } \\
\text { Generation Immigrants in Denmark }\end{array}$ & 3 & $1 / 00$ \\
\hline 102 & $\begin{array}{l}\text { B. van der Klaauw } \\
\text { J. C. van Ours }\end{array}$ & $\begin{array}{l}\text { Labor Supply and Matching Rates for Welfare } \\
\text { Recipients: An Analysis Using Neighborhood } \\
\text { Characteristics }\end{array}$ & $2 / 3$ & $1 / 00$ \\
\hline 103 & K. Brännäs & $\begin{array}{l}\text { Estimation in a Duration Model for Evaluating } \\
\text { Educational Programs }\end{array}$ & 6 & $1 / 00$ \\
\hline 104 & S. Kohns & $\begin{array}{l}\text { Different Skill Levels and Firing Costs in a } \\
\text { Matching Model with Uncertainty - } \\
\text { An Extension of Mortensen and Pissarides (1994) }\end{array}$ & 1 & $1 / 00$ \\
\hline 105 & $\begin{array}{l}\text { G. Brunello } \\
\text { C. Graziano } \\
\text { B. Parigi }\end{array}$ & $\begin{array}{l}\text { Ownership or Performance: What Determines } \\
\text { Board of Directors' Turnover in Italy? }\end{array}$ & 1 & $1 / 00$ \\
\hline
\end{tabular}


1979 - 1990: An analysis of the (West-)German multivariate failure times and unobserved heterogeneity

107 J. C. van Ours G. Ridder

J. Boone

J. C. van Ours

109 G. J. van den Berg

B. van der Klaauw

110 D. DeVoretz

C. Werner

111 V. Sorm

K. Terrell

112

L. Bellmann

T. Schank

113 R. Euwals

114 G. Brunello

A. Medio

115 A. Cigno

F. C. Rosati

116

C. Belzil

S. Bender

A. Haas

C. Klose

118 M. A. Shields

M. E. Ward

119 A. Lindbeck

D. J. Snower

120 P. T. Pereira

P. S. Martins

121

J. C. van Ours

122

D. Munich

J. Svejnar

K. Terrell

123 J. Hunt
Fast Track or Failure: A Study of the Completion

Rates of Graduate Students in Economics

Modeling Financial Incentives to Get Unemployed Back to Work

Combining Micro and Macro Unemployment

Duration Data

A Theory of Social Forces and Immigrant Second

Language Acquisition

Sectoral Restructuring and Labor Mobility:

A Comparative Look at the Czech Republic

Innovations, Wages and Demand for

5

$1 / 00$

Heterogeneous Labour: New Evidence from a

Matched Employer-Employee Data-Set

Do Mandatory Pensions Decrease Household

Savings? Evidence for the Netherlands

An Explanation of International Differences in

Education and Workplace Training

Why do Indian Children Work, and is it Bad for

3

$2 / 00$

Them?

Unemployment Insurance and Subsequent Job

Duration: Job Matching vs. Unobserved

Heterogeneity

IAB Employment Subsample 1975-1995.

Opportunities for Analysis Provided by the

Anonymised Subsample

Improving Nurse Retention in the British National

Health Service: The Impact of Job Satisfaction on

5

$2 / 00$

Intentions to Quit

The Division of Labor and the Market for

Organizations

Does Education Reduce Wage Inequality?

Quantile Regressions Evidence from Fifteen

European Countries

3

$2 / 00$

$2 / 00$

Do Active Labor Market Policies Help Unemployed $\quad 4 / 6 \quad 3 / 00$

Workers to Find and Keep Regular Jobs?

Returns to Human Capital under the Communist

Wage Grid and During the Transition to a Market

4

$3 / 00$

Economy

Why Do People Still Live in East Germany? 
125 F. Büchel of Social Assistance Benefits

J. R. Frick

The Income Portfolio of Immigrants in Germany $1 / 3$

$3 / 00$

Effects of Ethnic Origin and Assimilation. Or:

Who Gains from Income Re-Distribution?

126 J. Fersterer

Smoking, Discount Rates, and Returns to

R. Winter-Ebmer

Education

127 M. Karanassou

Characteristics of Unemployment Dynamics: The

Chain Reaction Approach

D. J. Snower

Do Unemployment Insurance Recipients Actively

Seek Work? Evidence From Randomized Trials in

Four U.S. States

129 B. R. Chiswick

M. E. Hurst

The Employment, Unemployment and

Unemployment Compensation Benefits of

Immigrants

130 G. Brunello

S. Comi

C. Lucifora

The Returns to Education in Italy: A New Look at

5

$3 / 00$

the Evidence

131 B. R. Chiswick

132

R. A. Hart

Are Immigrants Fa

Hours and Wages in the Depression: British 7

133 D. N. F. Bell

Paid and Unpaid Overtime Working in Germany and 1

R. A. Hart

O. Hübler

W. Schwerdt

the UK

134 A. D. Kugler

G. Saint-Paul

135 A. Barrett

P. J. O'Connell

136 M. Bräuninger

M. Pannenberg

Hiring and Firing Costs, Adverse Selection and

3

$3 / 00$

Long-term Unemployment

Is There a Wage Premium for Returning Irish

$3 / 00$

Migrants?

Unemployment and Productivity Growth: An

$3 / 00$

Empirical Analysis within the Augmented Solow

3

Model

137 J.-St. Pischke

Continuous Training in Germany

138 J. Zweimüller

R. Winter-Ebmer

Firm-specific Training: Consequences for Job

Mobility

139 R. A. Hart

Y. Ma

Wages, Hours and Human Capital over the

$3 / 00$

140 G. Brunello

Life Cycle

1

Education and Earnings Growth: Evidence from $11 \quad$ 2/5 4/00

S. Comi

European Countries

141 R. Hujer

M. Wellner

The Effects of Public Sector Sponsored Training on

Individual Employment Performance in East

6

$4 / 00$

Germany 

both Worlds?

Does the Recent Success of Some OECD Countries in Lowering their Unemployment Rates Lie in the Clever Design of their Labour Market Reforms?

Employment Effects of Labour Taxation in an Efficiency Wage Model with Alternative Budget Constraints and Time Horizons

149 R. Lalive

J. C. van Ours

J. Zweimüller

150 J. DiNardo

K. F. Hallock

J.-St. Pischke

$151 \quad$ M. Ward

152 J. J. Dolado

F. Felgueroso

J. F. Jimeno

153 A. S. Kalwij

M. Gregory

154 M. Gerfin

M. Lechner

155 J. Hansen

156 C. Dustmann

F. Fabbri

157 P. Apps

R. Rees

158 A. Björklund

T. Eriksson

M. Jäntti

O. Raaum

E. Österbacka

The Impact of Active Labor Market Programs and Benefit Entitlement Rules on the Duration of

Unions and the Labor Market for Managers

Gender, Salary and Promotion in the Academic Profession

The Role of the Minimum Wage in the Welfare 3

Microeconometric Evaluation of the Active Labour 6

The Duration of Immigrant
Evidence from Sweden

Language Proficiency and Labour Market Per- 1

formance of Immigrants in the UK

Household Production, Full Consumption and $\quad 7$ the Costs of Children

Brother Correlations in Earnings in Denmark, 5 Finland, Norway and Sweden Compared to the United States 
A Comparison of the Human Capital and Signaling Models: The Case of the Self-Employed and the Barrachina

Selection Correction in Panel Data Models: An Application to Labour Supply and Wages The Recent Danish Experience

Wages and the Demand for Health - A Life Cycle Analysis

Reforming the Financial Incentives of the Welfare System Skilled Immigrants in the United States 
177 B. R. Chiswick

G. Repetto

178 R. Euwals M. Ward

179 E. Wasmer

P. Weil

180 T. K. Bauer

I. N. Gang

181 E. Wasmer

Y. Zenou

182 M. Fertig

C. M. Schmidt

183 M. Fertig

C. M. Schmidt

184 M. Corak

B. Gustafsson

T. Österberg
Immigrant Adjustment in Israel: Literacy and

1

$7 / 00$

Fluency in Hebrew and Earnings

The Renumeration of British Academics

5

$7 / 00$

The Macroeconomics of Labor and Credit Market Imperfections

Sibling Rivalry in Educational Attainment:

The German Case

Space, Search and Efficiency

2

$8 / 00$

Discretionary Measures of Active Labor Market

Policy: The German Employment Promotion Reform in Perspective

Aggregate-Level Migration Studies as a Tool for 1 Forecasting Future Migration Streams

Intergenerational Influences on the Receipt of 3 Unemployment Insurance in Canada and Sweden 